Check for updates

Cite this: RSC Adv., 2019, 9, 15615

\title{
A magnetically separable plate-like cadmium titanate-copper ferrite nanocomposite with enhanced visible-light photocatalytic degradation performance for organic contaminants
}

\author{
Kosar Jahanara and Saeed Farhadi (iD *
}

\begin{abstract}
A novel magnetic cadmium titanate-copper ferrite $\left(\mathrm{CdTiO}_{3} / \mathrm{CuFe}_{2} \mathrm{O}_{4}\right)$ nanocomposite, in which spherical $\mathrm{CuFe}_{2} \mathrm{O}_{4}$ nanoparticles were loaded onto the surface of $\mathrm{CdTiO}_{3}$ nanoplates, was successfully synthesized via a sol-gel hydrothermal route at $180{ }^{\circ} \mathrm{C}$. The structure, morphology, magnetic and optical properties of the as-prepared nanocomposite were respectively characterized by Fourier transform infrared (FT-IR) spectroscopy, X-ray diffraction (XRD), field emission scanning electron microscopy (FESEM), energy dispersive X-ray (EDX) spectroscopy, transmission electron microscopy (TEM), Brunauer-Emmett-Teller (BET) surface area analysis, UV-visible diffuse reflectance spectroscopy (DRS), vibrating sample magnetometry (VSM) and photoluminescence (PL) spectroscopy. The photocatalytic activity of this novel $\mathrm{CdTiO}_{3}$-based magnetic nanocomposite was investigated for the degradation of organic dye pollutants such as methylene blue (MB), rhodamine $B(R h B)$, and methyl orange (MO) in the presence of $\mathrm{H}_{2} \mathrm{O}_{2}$ under visible light irradiation. The results showed that the photocatalyst completely degraded three dyes within 90-100 min. Compared with pure $\mathrm{CdTiO}_{3}$ and $\mathrm{CuFe}_{2} \mathrm{O}_{4}$, the heterogeneous $\mathrm{CdTiO}_{3} / \mathrm{CuFe}_{2} \mathrm{O}_{4}$ nanocomposite exhibited significantly enhanced photocatalytic efficiency. On the basis of the results of the $\mathrm{OH}$ trapping and photoluminescence $(\mathrm{PL})$ experiments, the enhanced photocatalytic performance was mainly ascribed to the efficient separation of photo-induced electron-hole pairs and the formation of highly active hydroxyl radicals $(\mathrm{OH})$ species in the $\mathrm{CdTiO}_{3} / \mathrm{CuFe}_{2} \mathrm{O}_{4}$ photocatalytic oxidation system. The $\mathrm{PL}$ measurements of the $\mathrm{CdTiO} / \mathrm{CuFe}_{2} \mathrm{O}_{4}$ nanocomposite also indicated an enhanced separation of photo-induced electron-hole pairs. Moreover, the nanocomposite could be easily separated and recycled from contaminant solution using a magnet without a decrease in their photocatalytic activity due to their good magnetic separation performance and excellent chemical stability. Based on these findings, $\mathrm{CdTiO}_{3} / \mathrm{CuFe}_{2} \mathrm{O}_{4}$ nanocomposite could be a promising visible-light-driven magnetic photocatalyst for converting solar energy to chemical energy for environmental remediation.
\end{abstract}

Received 14th March 2019

Accepted 14th May 2019

DOI: $10.1039 / c 9 r a 01968 \mathrm{e}$

rsc.li/rsc-advances

\section{Introduction}

Nowadays, the world energy crisis and environmental pollution have become main issues in the lives of humans. ${ }^{\mathbf{1} 2}$ Organic dye effluents from the textile and dyeing industries are one of the largest groups of pollutants discharged into the environment without adequate treatment. ${ }^{3}$ Although conventional biological, physical, and chemical methods have been established for wastewater treatment, in these cases, the pollutant is only transferred from the liquid phase to the solid phase and further treatment is necessary to purify the resulting sludge. ${ }^{4-10}$ Additionally, pollutants with very low concentrations are still difficult to remove from wastewater. ${ }^{11}$ Advanced oxidation processes

Department of Chemistry, Lorestan University, Khorramabad 68151-44316, Iran. E-mail: farhadi.s@lu.ac.ir; sfarhadi1348@yahoo.com; Fax: +986633120618; Tel: $+986633120611$
(AOPs) have been used to eliminate a wide range of organic contaminants from water and air. ${ }^{12}$ In this context, heterogeneous photocatalysis is considered one of the most potent AOPs because of its potential applications in the degradation of organic contaminants. ${ }^{13-16}$ Among the various AOPs, the semiconductorbased photocatalysis is an effective and low-cost strategy for the treatment of water pollutants and disinfection. ${ }^{17}$ In this method, organic compounds can be completely degraded to $\mathrm{H}_{2} \mathrm{O}$ and $\mathrm{CO}_{2}$ by photocatalysis and no secondary pollutants are generated. ${ }^{\mathbf{1 8 , 1 9}}$

Metal oxide-based semiconductor photocatalysts have been extensively applied in the field of environmental remediation due to their unique physicochemical properties, nontoxicity, and excellent photocatalytic activity. ${ }^{20-24}$ In recent decades, titanium dioxide $\left(\mathrm{TiO}_{2}\right)$ has attracted considerable attention due to its low-cost, nontoxicity, and chemical inertness. ${ }^{25}$ Nevertheless, its use is limited to UV light irradiation due to its wide band gap structure $(3.2 \mathrm{eV}) .{ }^{26,27}$ It is well known that UV 
light is just $4 \%$ of solar radiation, while visible light is about $43 \%$. Therefore, the design and synthesis of highly efficient visible-light-driven photocatalysis is an important research focus. ${ }^{28-30}$

Over the past several years, titanium-based perovskite-type oxides with formula of $\mathrm{MTiO}_{3}\left(\mathrm{M}=\mathrm{Ca}^{2+}, \mathrm{Ba}^{2+}, \mathrm{Sr}^{2+}, \mathrm{Pb}^{2+}, \ldots\right)$ have been widely studied because of their ferroelectric, dielectric, piezoelectric, pyroelectric and photostrictive properties, which make these ceramics eligible to be defined as 'smart'. ${ }^{31}$ They also showed interesting properties as non-linear optics and humidity sensors. Among this smart family, cadmium titanate $\left(\mathrm{CdTiO}_{3}\right)$ is much less studied because it is not ferroelectric at room temperature. From a fundamental point of view, however, $\mathrm{CdTiO}_{3}$ represents an interesting system for the investigation of the nature of the ferroelectric and structural phase transitions. ${ }^{32-35}$ Cadmium titanate has also been used as a conductive material, ${ }^{36,37}$ optical fibers, ${ }^{38}$ and humidity sensing. ${ }^{39}$ In addition, like other titanium-based systems, there is the possibility that it may have unexplored potential for application in photocatalysis. ${ }^{40}$ However, little previous studies showed that the $\mathrm{CdTiO}_{3}$ with a wide band gap of $3.5 \mathrm{eV}$ like $\mathrm{TiO}_{2}$ has no significant photocatalytic activity under visible light irradiation. ${ }^{22}$ Forming a heterostructure by combining $\mathrm{CdTiO}_{3}$ with a narrow band-gap semiconductor is an effective route to enhance the visible-light response and improve the charge separation efficiency. ${ }^{\mathbf{4 1}}$

Nanostructured spinel-type ferrites $\left(\mathrm{MFe}_{2} \mathrm{O}_{4} ; \mathrm{M}=\mathrm{Mn}^{2+}\right.$, $\left.\mathrm{Fe}^{2+}, \mathrm{Co}^{2+}, \mathrm{Ni}^{2+}, \mathrm{Cu}^{2+}, \mathrm{Zn}^{2+}, \ldots\right)$ have been considered as a promising candidate for efficient photocatalysts because of their small band gaps (1.3-2.1 eV), high photochemical stability, low cost, easy synthesis and unique magnetic properties. $^{42}$ For these reasons, the use of nanoscale spinel-type ferrites in the fabrication of magnetic photocatalyst nanocomposite is very beneficial. ${ }^{\mathbf{4 3}-46}$ Thus, it is possible to improve the efficiency of photoinduced charge separation in $\mathrm{CdTiO}_{3}$ by coupling it with magnetic spinel-type $\mathrm{CuFe}_{2} \mathrm{O}_{4}$ nanoparticles, resulting in high photocatalytic performance. Furthermore, its magnetic nature makes composite magnetically separable from the reaction mixture in a convenient manner.

In the present study, a novel magnetic cadmium titanatebased photocatalyst $\left(\mathrm{CdTiO}_{3} / \mathrm{CuFe}_{2} \mathrm{O}_{4}\right)$ composite was prepared by a facile sol-gel hydrothermal route. The composition, microstructure and optical properties of the synthesized nanocomposite were fully characterized by various physical techniques. The visible-light photocatalytic activity of $\mathrm{CdTiO}_{3} /$ $\mathrm{CuFe}_{2} \mathrm{O}_{4}$ nanocomposite was evaluated based on the degradation of organic dyes in the presence of $\mathrm{H}_{2} \mathrm{O}_{2}$. The effects of various parameters (e.g. $\mathrm{H}_{2} \mathrm{O}_{2}$ quantity, the catalyst dosage, and initial dye concentration) on the degradation process were also investigated. Furthermore, the activity of $\mathrm{CdTiO}_{3} / \mathrm{CuFe}_{2} \mathrm{O}_{4}$ nanocomposite was compared with those of pure $\mathrm{CdTiO}_{3}$ and $\mathrm{CuFe}_{2} \mathrm{O}_{4}$ under similar conditions. Furthermore, a possible mechanism for solar-light photoactivity of the nanocomposite was proposed. To the best of our knowledge, there are no reports on the preparation and photocatalytic properties of magnetic $\mathrm{CdTiO}_{3}$-based hybrids in the degradation of aqueous organic pollutants under visible light.

\section{Experimental}

\subsection{Materials}

Cadmium acetate $\left(\mathrm{Cd}\left(\mathrm{CH}_{3} \mathrm{COO}\right)_{2}, 98 \%\right)$, tetrabutyl orthotitanate $\left(\mathrm{Ti}\left(\mathrm{C}_{4} \mathrm{H}_{9} \mathrm{O}\right)_{4}, 99 \%\right)$, iron(III) chloride hexahydrate $\left(\mathrm{FeCl}_{3}\right.$ $\left.\cdot 6 \mathrm{H}_{2} \mathrm{O}, 98 \%\right)$, copper(II) chloride dehydrate $\left(\mathrm{CuCl}_{2} \cdot 2 \mathrm{H}_{2} \mathrm{O}, 98 \%\right)$, sodium acetate $\left(\mathrm{CH}_{3} \mathrm{COONa}, 98 \%\right)$, potassium hydroxide $(\mathrm{KOH}$, $98 \%)$, glycerol $\left(\mathrm{C}_{3} \mathrm{H}_{8} \mathrm{O}_{3}, 99 \%\right)$, ethanol $\left(\mathrm{C}_{2} \mathrm{H}_{5} \mathrm{OH}, 98 \%\right)$, acetic acid $\left(\mathrm{CH}_{3} \mathrm{COOH}\right)$, diethyl ether $\left(\left(\mathrm{C}_{2} \mathrm{H}_{5}\right)_{2} \mathrm{O}\right)$, hydrogen peroxide $\left(\mathrm{H}_{2} \mathrm{O}_{2}, 30 \%\right)$, methylene blue ( $\mathrm{MB}, \mathrm{C}_{16} \mathrm{H}_{18} \mathrm{ClN}_{3} \mathrm{~S}$, 98\%), methyl orange ( $\mathrm{MO}, \mathrm{C}_{14} \mathrm{H}_{14} \mathrm{~N}_{3} \mathrm{NaO}_{3} \mathrm{~S}, 98 \%$ ), and rhodamine $\mathrm{B}$ ( $\mathrm{RhB}$, $\mathrm{C}_{28} \mathrm{H}_{31} \mathrm{ClN}_{2} \mathrm{O}_{3}, 98 \%$ ) were purchased from Merck chemical company and used as received.

\subsection{Characterization techniques}

XRD patterns were measured on a XPertPro Panalytical X-ray diffractometer instrument with $\mathrm{Cu} \mathrm{K} \alpha$ radiation $(\lambda=1.54056$ $\AA)$ in the range $2 \theta=10-80^{\circ}$ with a scan speed of $10^{\circ} \mathrm{min}^{-1}$. Infrared spectra were recorded from Schimadzu FT-IR 160 spectrophotometer in transmission mode from 4000 to $400 \mathrm{~cm}^{-1}$ using $\mathrm{KBr}$ pellets. The morphology and elemental analysis of the $\mathrm{CdTiO}_{3} / \mathrm{CuFe}_{2} \mathrm{O}_{4}$ nanocomposite were observed by Field emission scanning electron microscopy-energy-dispersive X-ray spectroscopy (FESEM-EDX) on a Mira3 Tescan scanning electron microscope equipped with an energy-dispersive X-ray unit. Transmission electron microscopy (TEM) images were taken on EM10C electron microscope operating at $n$ voltage of $100 \mathrm{kV}$. Magnetic measurements were employed using a vibrating sample magnetometer (VSM, Daneshpajoh Kashan Co, Iran) with a maximum magnetic field of $10 \mathrm{kOe}$ at room temperature. The UV-vis diffuse reflectance spectra (DRS) were obtained on a Sinico S4100 spectrophotometer using $\mathrm{BaSO}_{4}$ powder as a standard. UV-Vis spectra of dye solutions were analyzed at room temperature using a Cary 100 UV-visible spectrophotometer. The Brunauer-EmmettTeller (BET) analysis was performed to obtain a specific surface area of $\mathrm{CdTiO}_{3} / \mathrm{CuFe}_{2} \mathrm{O}_{4}$ nanocomposite by a PHS-1020 PHSCHINA instrument. The photoluminescence (PL) spectra were measured using a fluorescence spectrophotometer of the samples (F-4500, Hitachi) at an excitation wavelength of $330 \mathrm{~nm}$. The loading amount of $\mathrm{CuFe}_{2} \mathrm{O}_{4}$ in the composite adsorbent and the concentrations of $\mathrm{Cu}$ and $\mathrm{Fe}$ metals in the filtrates and solutions after recovering photocatalyst were determined by inductively coupled plasma atomic emission spectrometer (PerkinElmer ICP-AES, USA).

\subsection{Synthesis of $\mathrm{CuFe}_{2} \mathrm{O}_{4}$ nanoparticles}

In a typical experiment, $0.54 \mathrm{~g} \mathrm{FeCl}_{3} \cdot 6 \mathrm{H}_{2} \mathrm{O}$ and $0.14 \mathrm{~g} \mathrm{CuCl}_{2}$ $\cdot 2 \mathrm{H}_{2} \mathrm{O}$ were dissolved in $30 \mathrm{~mL}$ of $1: 1$ glycerol-water solution by magnetic stirring for $30 \mathrm{~min}$. Then, $0.8 \mathrm{~g} \mathrm{NaCH} \mathrm{NOOO}_{3} \cdot 3 \mathrm{H}_{2} \mathrm{O}$ was added into the mixed solution under vigorous stirring for $20 \mathrm{~min}$. The mixture was then poured into a Teflon-lined stainless steel autoclave of $40 \mathrm{~mL}$ capacity. The autoclave was placed in an electric oven at a temperature of $200{ }^{\circ} \mathrm{C}$ for $12 \mathrm{~h}$. After $12 \mathrm{~h}$, the autoclave was allowed to cool to room 
temperature. The product was separated by and washed with deionized water 3 times before being dried at $60{ }^{\circ} \mathrm{C}$ overnight.

\subsection{Synthesis of the $\mathrm{CdTiO}_{3} / \mathrm{CuFe}_{2} \mathrm{O}_{4}$ nanocomposite}

In a typical procedure, cadmium acetate $(1.5 \mathrm{mmol})$ was dissolved in distilled water $(15 \mathrm{~mL})$. Then, it was introduced into a prepared solution of tetrabutyl orthotitanate $(1.5 \mathrm{mmol})$ which was dissolved in ethanol $(15 \mathrm{~mL})$. After stirring for $15 \mathrm{~min}, \mathrm{CH}_{3} \mathrm{COOH}(0.3 \mathrm{~mL})$ was added to the mixture to control the hydrolysis of tetrabutyl orthotitanate. To this mixture $0.2 \mathrm{~g}$ $\mathrm{CuFe}_{2} \mathrm{O}_{4}$ nanoparticles sonicated in $10 \mathrm{~mL}$ of deionized water was added. The mixture was stirred at room temperature for $5 \mathrm{~h}$, afterward it was kept under magnetic stirring at $40{ }^{\circ} \mathrm{C}$ constantly. With the evaporation of water and $\mathrm{CH}_{3} \mathrm{COOH}$, a light yellow transparent gelatin, as the unique starting source of this hydrothermal preparation, was prepared. Then sufficient amount of the gelatin was put into a $50 \mathrm{~mL}$ Teflon-lined stainless autoclave. The autoclave was filled with $\mathrm{KOH}(1 \mathrm{M})$ solution up to $80 \%$ of its total volume and maintained at $200{ }^{\circ} \mathrm{C}$ for $24 \mathrm{~h}$, the resulting precipitates were filtered, washed with distilled water, ethanol and ether and then dried at ambient temperature. The ICP-AES results indicated that the loading amount of $\mathrm{CuFe}_{2} \mathrm{O}_{4}$ in the as-prepared $\mathrm{CdTiO}_{3} / \mathrm{CuFe}_{2} \mathrm{O}_{4}$ nanocomposite was estimated to be $38 \mathrm{wt} \%$. For comparison, pure $\mathrm{CdTiO}_{3}$ powder was prepared by using current method in the absence of $\mathrm{CuFe}_{2} \mathrm{O}_{4}$.

\subsection{Photocatalytic tests}

The photocatalytic activities of the as-synthesized samples were evaluated by the degradation of MB dye aqueous solution under visible-light irradiation. All experiments were carried out in a cylindrical Pyrex cell with a $400 \mathrm{~W}$ high-pressure mercury lamp with a UV-cutoff filter as the visible-light irradiation source $(\lambda \geq 420 \mathrm{~nm}$ ), and temperature was controlled by the circulating water. In a typical procedure, $30 \mathrm{mg}$ of assynthesized materials were dispersed into $30 \mathrm{~mL}$ of dyes aqueous solution and the suspensions were shaken for $30 \mathrm{~min}$ in the dark prior to visible-light illumination to obtain an adsorption-desorption equilibrium. After that, $0.5 \mathrm{~mL}$ of $30 \%$ $\mathrm{H}_{2} \mathrm{O}_{2}$ was added to the mixture, and then irradiated. $2 \mathrm{~mL}$ aliquot of the reaction solution was collected regularly at a certain time interval, and the photocatalyst was separated using an external magnet. The MB dye absorption intensity was measured at maximum absorbance wavelength of $664 \mathrm{~nm}$ via a UV-Vis spectrophotometer. The degradation efficiency of the $\mathrm{MB}$ was calculated using the following equation:

$$
\text { Degradation efficiency }(\%)=100\left(C_{0}-C_{t}\right) / C_{0}
$$

whereas $C_{0}$ and $C_{t}$ are the initial concentration of dye and concentration after regular irradiation, respectively. Similar experiments were conducted to evaluate the effect of initial dye concentration $\left(12.5,25,37.5,50 \mathrm{mg} \mathrm{L}^{-1}\right)$, catalyst dosage $(10,20$, $30,40,50 \mathrm{mg})$ and amount of $30 \% \mathrm{H}_{2} \mathrm{O}_{2}(0,0.25,0.5,0.75,1 \mathrm{~mL})$ on the photocatalytic activity of $\mathrm{CdTiO}_{3} / \mathrm{CuFe}_{2} \mathrm{O}_{4}$ nanocomposite. To investigate the photocatalytic stability and reusability of the samples, the photocatalytic activity measurements mentioned above were repeated for 5 cycles using an aqueous MB solution ( $25 \mathrm{mg} \mathrm{L}^{-1}$ ). After each cycle, the spent photocatalyst was separated from the treated MB solution, washed with deionized water, dried in an oven, and used again for the next photodegradation cycle. Photocatalytic activity of the $\mathrm{CdTiO}_{3} / \mathrm{CuFe}_{2} \mathrm{O}_{4}$ was also evaluated by the degradation of $\mathrm{RhB}$ and $\mathrm{MO}$ aqueous solution in a same manner. To detect the active species generated in the photodegradation process, the scavengers isopropyl alcohol (IPA; $5 \mathrm{mmol} \mathrm{L}^{-1}$ ), and disodium ethylenediaminetetraacetate $\left(\mathrm{Na}_{2} \mathrm{EDTA} ; 5 \mathrm{mmol} \mathrm{L} \mathrm{L}^{-1}\right)$ were added into the solution of MB. The photocatalytic process was the same as that described in the above.

\section{Results and discussion}

\subsection{FTIR analysis}

FT-IR spectra of pure $\mathrm{CuFe}_{2} \mathrm{O}_{4}$, pristine $\mathrm{CdTiO}_{3}$ and $\mathrm{CdTiO}_{3} /$ $\mathrm{CuFe}_{2} \mathrm{O}_{4}$ nanocomposite are shown in Fig. 1. In Fig. 1(a), a characteristic band at around $580 \mathrm{~cm}^{-1}$ corresponds to the stretching vibration of $\mathrm{Fe}-\mathrm{O}$ bond, confirms the formation of magnetic $\mathrm{CuFe}_{2} \mathrm{O}_{4}$ nanoparticles. ${ }^{47}$ Fig. 1 (b) indicates the FT-IR spectrum of pure $\mathrm{CdTiO}_{3}$ phase. Absorption peaks at 711, 526 and $426 \mathrm{~cm}^{-1}$ can be related to the stretching vibrations of $\mathrm{O}-$ Ti-O, Ti-O, Cd-O bands, respectively. ${ }^{48}$ These results provided that $\mathrm{CdTiO}_{3}$ was successfully synthesized. As shown in Fig. 1(c),

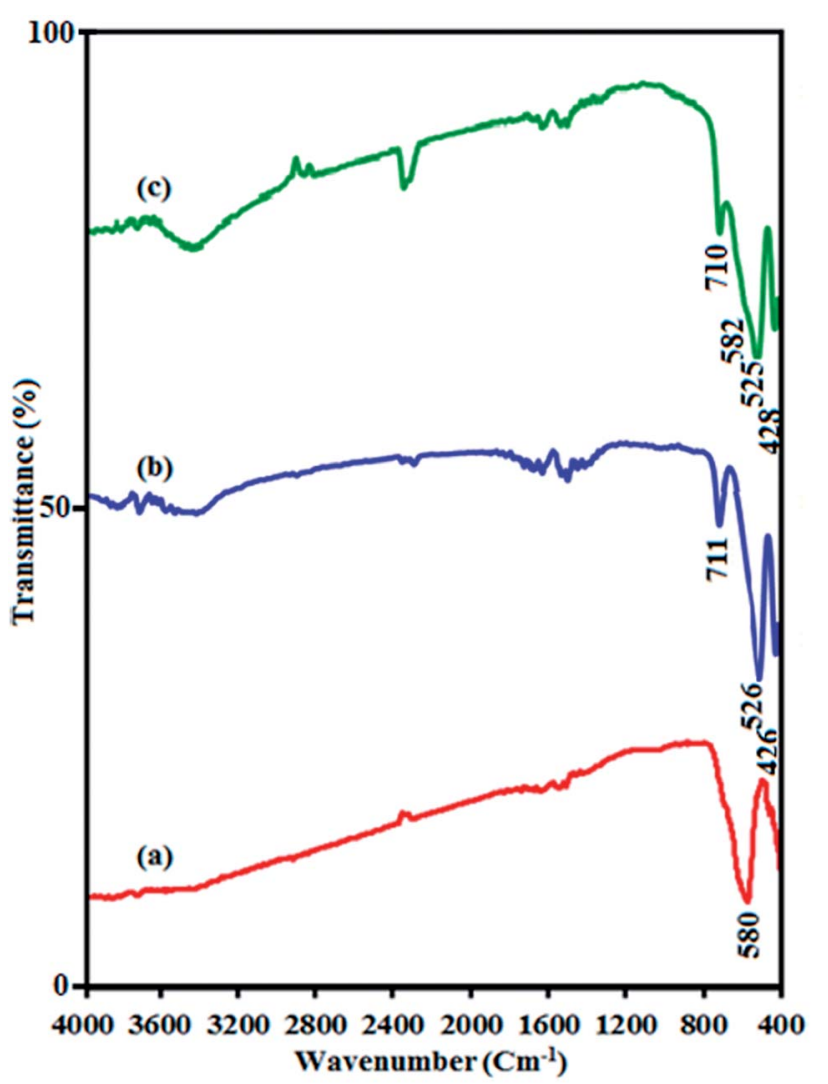

Fig. 1 FT-IR spectra of (a) $\mathrm{CuFe}_{2} \mathrm{O}_{4}$, (b) $\mathrm{CdTiO}_{3}$ and (c) $\mathrm{CdTiO}_{3} /$ $\mathrm{CuFe}_{2} \mathrm{O}_{4}$ 
the characteristic spectral bands verified the existence of the both $\mathrm{CdTiO}_{3}$ and $\mathrm{CuFe}_{2} \mathrm{O}_{4}$ in the $\mathrm{CdTiO}_{3} / \mathrm{CuFe}_{2} \mathrm{O}_{4}$ nanocomposite and two broad peak were also observed at about 2800-3700 $\mathrm{cm}^{-1}$ and $1400-1700 \mathrm{~cm}^{-1}$ due to the stretching vibration and deformation of the absorbed water molecules. ${ }^{\mathbf{4 9}}$ The characteristic band of $\mathrm{CuFe}_{2} \mathrm{O}_{4}$ in the nanocomposite appeared as a shoulder at $582 \mathrm{~cm}^{-1}$ due to overlapping with the stretching band of $\mathrm{CdTiO}_{3}$ at $525 \mathrm{~cm}^{-1}$.

\subsection{XRD analysis}

Fig. 2 shows the XRD patterns of $\mathrm{CuFe}_{2} \mathrm{O}_{4}, \mathrm{CdTiO}_{3}$ and $\mathrm{CdTiO}_{3} /$ $\mathrm{CuFe}_{2} \mathrm{O}_{4}$. The diffraction peaks of spinel-type $\mathrm{CuFe}_{2} \mathrm{O}_{4}$ nanoparticles at $35.4^{\circ}, 43.3^{\circ}, 53.6^{\circ}, 57.1^{\circ}$ and $62.7^{\circ}$ in Fig. 2(a) are assigned to the (261), (400), (422), (511), and (440) planes (JCPDS card no. 25-0283), respectively. ${ }^{50}$ In addition, the diffraction peaks appeared at $17.9^{\circ}, 20.4^{\circ}, 22.9^{\circ}, 31.1^{\circ}, 34.1^{\circ}$, $53.7^{\circ}$ and $59.3^{\circ}$ can be indexed as (003), (101), (012), (104), (110), (116) and (214) diffraction planes of $\mathrm{CdTiO}_{3}$ phase (JCPDS, card no. 29-0277), respectively (Fig. 2(b)). ${ }^{51}$ It is obvious in Fig. 2(c) that the XRD pattern of nanocomposite sample exhibits diffraction peaks corresponding to both $\mathrm{CuFe}_{2} \mathrm{O}_{4}$ and $\mathrm{CdTiO}_{3}$ phases and no other impure peaks can be observed, indicating that this sample is composed of $\mathrm{CuFe}_{2} \mathrm{O}_{4}$ and $\mathrm{CdTiO}_{3}$ phases

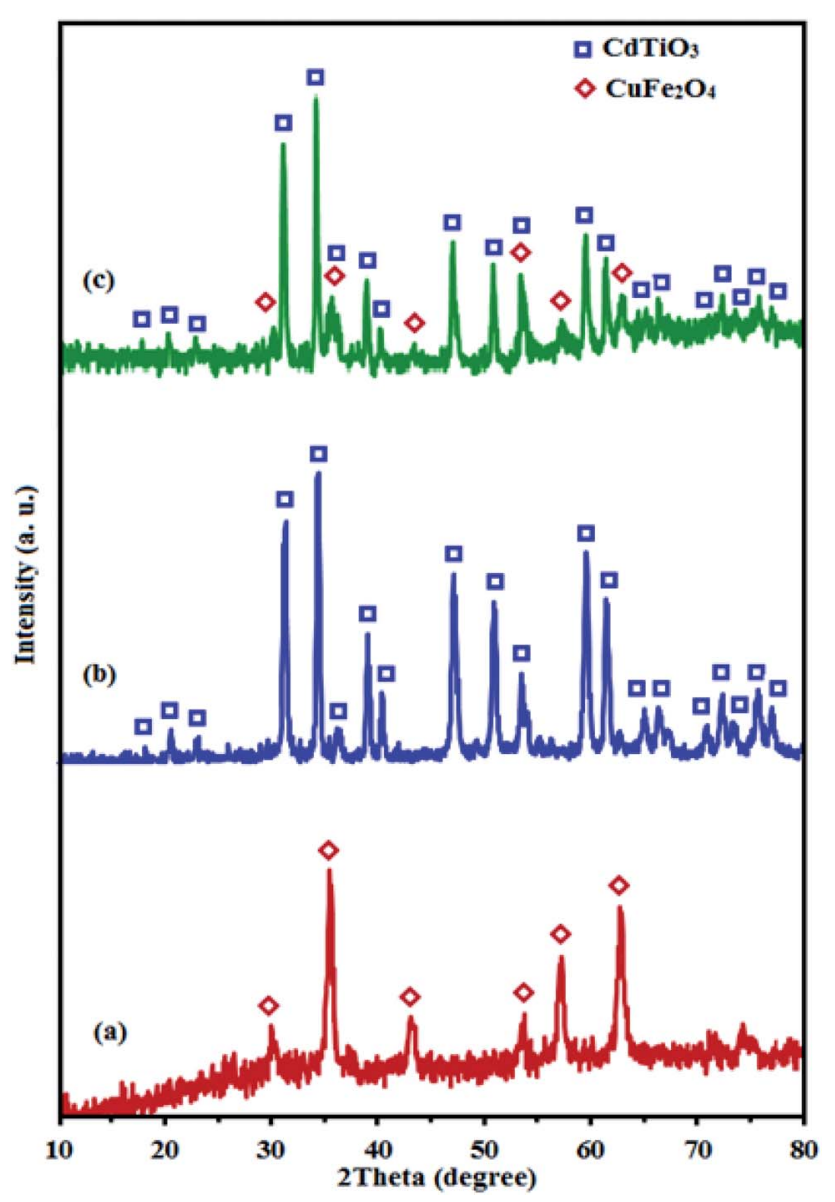

Fig. 2 XRD patterns of (a) $\mathrm{CuFe}_{2} \mathrm{O}_{4}$, (b) $\mathrm{CdTiO}_{3}$ and (c) $\mathrm{CdTiO}_{3} /$ $\mathrm{CuFe}_{2} \mathrm{O}_{4}$. and the $\mathrm{CdTiO}_{3} / \mathrm{CuFe}_{2} \mathrm{O}_{4}$ composite has been successfully prepared. The diffraction peaks of 35.4 and 53.7 from $\mathrm{CuFe}_{2} \mathrm{O}_{4}$ overlapped with the peaks from $\mathrm{CdTiO}_{3}$, and the relative intensity of these peaks for $\mathrm{CdTiO}_{3} / \mathrm{CuFe}_{2} \mathrm{O}_{4}$ nanocomposite increased. The average size of the $\mathrm{CuFe}_{2} \mathrm{O}_{4}$ was found of about $20 \mathrm{~nm}$ using Debye-Scherrer equation: ${ }^{52} D_{\mathrm{XRD}}=0.9 \lambda /(\beta \cos \theta)$, where $D_{\mathrm{XRD}}$ is the average crystalline size, $\lambda$ is the wavelength of $\mathrm{Cu} \mathrm{K} \alpha$ radiation, $\beta$ is the full width at half maximum of the diffraction peak, and $\theta$ is the Bragg angle.

\subsection{SEM and EDX analyses}

The shape and morphology of the as-synthesized $\mathrm{CdTiO}_{3}$, $\mathrm{CuFe}_{2} \mathrm{O}_{4}$ and $\mathrm{CdTiO}_{3} / \mathrm{CuFe}_{2} \mathrm{O}_{4}$ samples were investigated by FESEM, and the results are shown in Fig. 3. The SEM images of $\mathrm{CuFe}_{2} \mathrm{O}_{4}$ sample in Fig. 3(a) show a large quantity of nearly uniform spherical nanoparticles with diameters $15-25 \mathrm{~nm}$. The SEM images in Fig. 3(b) and (c) show that the bare $\mathrm{CdTiO}_{3}$ sample was formed from nanoplates with smooth surface which were loosely aggregated. The thickness and width of nanoplates are estimated to be about $50 \mathrm{~nm}$ and 250-650 nm, respectively. As can be observed, the porous structure was formed by selfassembly of these nanoplates. SEM images of the $\mathrm{CdTiO}_{3} /$ $\mathrm{CuFe}_{2} \mathrm{O}_{4}$ nanocomposite are shown in Fig. 3(d)-(f). From the images, it is evident that the shape and morphology of $\mathrm{CdTiO}_{3} /$ $\mathrm{CuFe}_{2} \mathrm{O}_{4}$ are similar to those of the pure $\mathrm{CdTiO}_{3}$, but a lot of sphere-like $\mathrm{CuFe}_{2} \mathrm{O}_{4}$ nanoparticles are homogeneously distributed over the surfaces of plate-like $\mathrm{CdTiO}_{3}$ nanostructures.

The existence of elements in the nanocomposite was detected by EDX spectroscopy and the results are shown in Fig. 4. From EDX spectrum in Fig. 4(a), the $\mathrm{Cd}, \mathrm{Ti}, \mathrm{Cu}, \mathrm{Fe}$ and $\mathrm{O}$ elements are clearly observed at their corresponding keV values. The distribution of elements present in the nanocomposite was also studied using EDX mapping analysis, and the results are shown in the Fig. 4(b). The corresponding elemental mappings show all elements are uniformly distributed over the nanocomposite, confirming the homogeneity of the nanocomposite sample. These results confirm that the obtained product was formed with high purity.

\subsection{TEM analysis}

The size and microstructure of the as-prepared $\mathrm{CdTiO}_{3} / \mathrm{CuFe}_{2} \mathrm{O}_{4}$ sample were further investigated by TEM. The sample was sonicated in ethanol for $30 \mathrm{~min}$ and a drop of the suspension was dried on a carbon-coated microgrid for TEM measurements. The TEM images in Fig. 5 show that the nanocomposite was formed mainly from plate-like particles with a weak agglomeration. From the TEM images in Fig. 5(a) and (b), it is clear that the $\mathrm{CdTiO}_{3} / \mathrm{CuFe}_{2} \mathrm{O}_{4}$ contains a plate-like structure with the lengths of 250-650 $\mathrm{nm}$ and thicknesses of several nanometers. From images, it can be clearly seen that a lot of sphere-like $\mathrm{CuFe}_{2} \mathrm{O}_{4}$ nanoparticles were well deposited on $\mathrm{CdTiO}_{3}$ nanoplates. As evident from the images, the morphology of the $\mathrm{CdTiO}_{3} / \mathrm{CuFe}_{2} \mathrm{O}_{4}$ sample from TEM images agreed with the SEM results. After being loaded with $\mathrm{CuFe}_{2} \mathrm{O}_{4}$ nanoparticles, the plate-like structure of $\mathrm{CdTiO}_{3}$ is maintained but the distinct $\mathrm{CuFe}_{2} \mathrm{O}_{4}$ aggregates were attached to the edge 

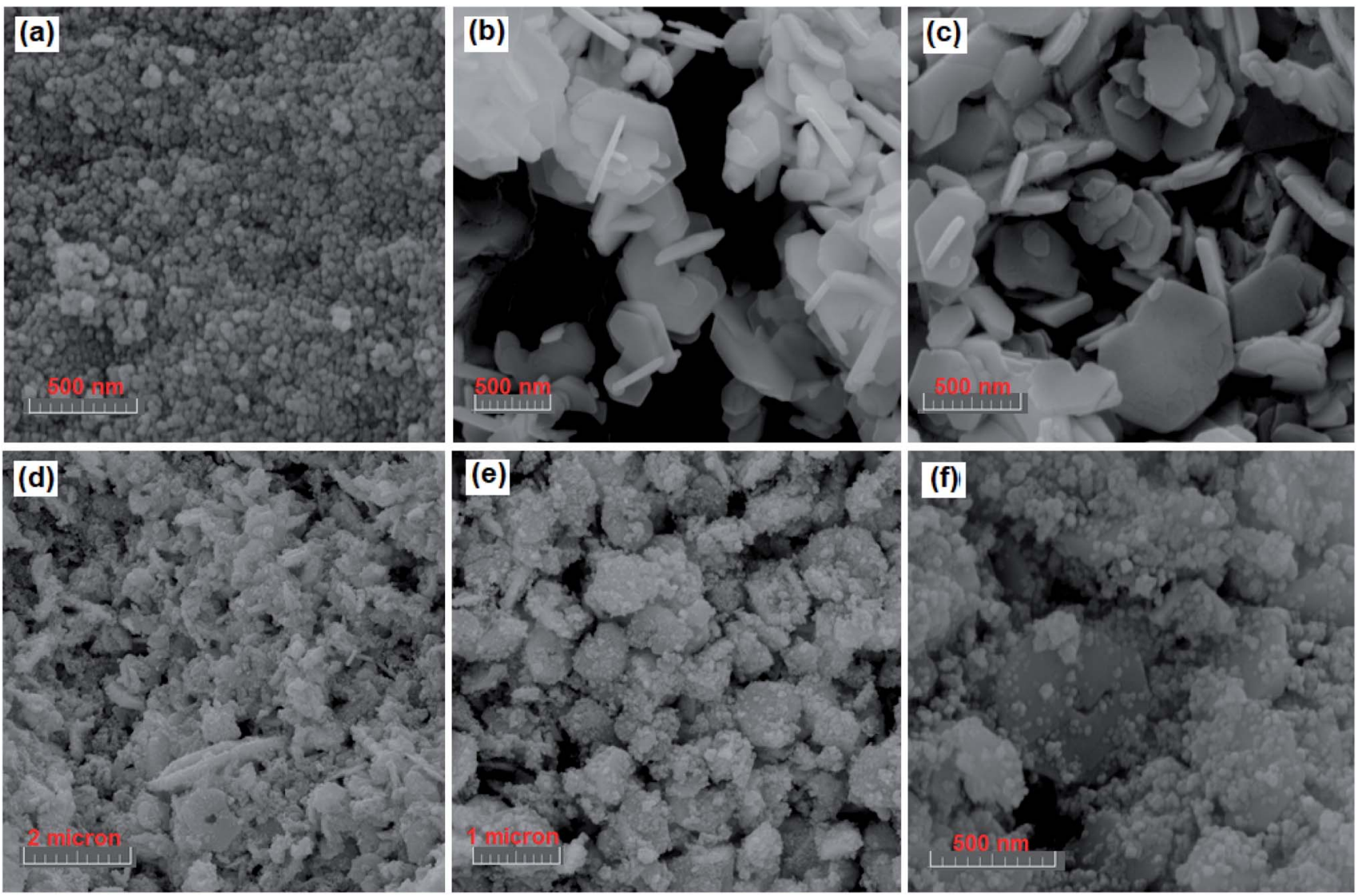

Fig. 3 SEM images (a) $\mathrm{CuFe}_{2} \mathrm{O}_{4}$, (b and c) $\mathrm{CdTiO}_{3}$, and (d-f) $\mathrm{CdTiO}_{3} / \mathrm{CuFe}_{2} \mathrm{O}_{4}$

and surface of the $\mathrm{CdTiO}_{3}$ sample. The synergistic interactions between $\mathrm{CuFe}_{2} \mathrm{O}_{4}$ and $\mathrm{CdTiO}_{3}$ led to decreased aggregation of the $\mathrm{CuFe}_{2} \mathrm{O}_{4}$ nanoparticles. The size of $\mathrm{CuFe}_{2} \mathrm{O}_{4}$ particles was calculated to be in the range of $15-25 \mathrm{~nm}$ from the measurements on the TEM micrographs which is in close agreement with the average size obtained from XRD analysis.

\subsection{BET surface area analysis}

Fig. 6 presents the $\mathrm{N}_{2}$ adsorption-desorption isotherms of pure $\mathrm{CuFe}_{2} \mathrm{O}_{4}$, pristine $\mathrm{CdTiO}_{3}$ and $\mathrm{CdTiO}_{3} / \mathrm{CuFe}_{2} \mathrm{O}_{4}$ nanocomposite samples. As shown in Fig. 6(a) and (b), $\mathrm{CdTiO}_{3}$ and $\mathrm{CdTiO}_{3} /$ $\mathrm{CuFe}_{2} \mathrm{O}_{4}$ composites display typical type IV isotherms with a $\mathrm{H} 3$ hysteresis loops according to the IUPAC classification, indicating the presence of large mesopores structures. ${ }^{53,54}$ The Brunauer-Emmett-Teller (BET) surface area values for $\mathrm{CuFe}_{2} \mathrm{O}_{4}, \mathrm{CdTiO}_{3}$ and $\mathrm{CdTiO}_{3} / \mathrm{CuFe}_{2} \mathrm{O}_{4}$ were calculated to be $43.512,14.023 \mathrm{~m}^{2} \mathrm{~g}^{-1}$ and $13.514 \mathrm{~m}^{2} \mathrm{~g}^{-1}$, respectively (Table 1). Obviously, there are only small differences among the surface area values of $\mathrm{CdTiO}_{3}$ and $\mathrm{CdTiO}_{3} / \mathrm{CuFe}_{2} \mathrm{O}_{4}$ samples. It is well known that the surface area is an important factor for enhanced photocatalytic activity due to the increase of adsorption activity and reaction sites. However, the photocatalytic activity of pure $\mathrm{CuFe}_{2} \mathrm{O}_{4}$, pristine $\mathrm{CdTiO}_{3}$ are lower than that of $\mathrm{CdTiO}_{3} /$ $\mathrm{CuFe}_{2} \mathrm{O}_{4}$ composite though their surface area and adsorption activity are the highest. The results indicate that there are other factors influencing the photocatalytic efficiency besides the specific surface area of one photocatalyst, including good visible light absorption properties, efficient charge transfer and the inhibition of electron-hole pairs recombination. It can be speculated that the different photocatalytic activity of the samples could not be determined by the BET surface areas in the process of dye degradation. Furthermore, we also calculated the pore size distributions by using the Barrett-Joyner-Halenda (BJH) method from the adsorption branches of the $\mathrm{N}_{2}$ isotherms (the insets of Fig. 6). The $\mathrm{CdTiO}_{3}$ and $\mathrm{CdTiO}_{3} /$ $\mathrm{CuFe}_{2} \mathrm{O}_{4}$ heterojunction samples have a broad pore size distribution centered at about 47.22 and $19.99 \mathrm{~nm}$, respectively which reveal the existence of nanopores. The presence of nanopores may serve as transport paths for organic pollutant molecules. As given in Table 1, the $\mathrm{CdTiO}_{3} / \mathrm{CuFe}_{2} \mathrm{O}_{4}$ heterojunction demonstrated a significant decrease pore volume and pore diameter compared with the pure $\mathrm{CuFe}_{2} \mathrm{O}_{4}$ and pristine $\mathrm{CdTiO}_{3}$ probably owing to the introduction of $\mathrm{CuFe}_{2} \mathrm{O}_{4}$ nanoparticles into the pores of the $\mathrm{CdTiO}_{3}$. The pores of $\mathrm{CdTiO}_{3} /$ $\mathrm{CuFe}_{2} \mathrm{O}_{4}$ were further occupied by the $\mathrm{CuFe}_{2} \mathrm{O}_{4}$ nanoparticles which resulted in a further decrease in pore volume and surface area.

\subsection{Optical properties analysis}

UV-vis diffuse reflectance spectra of the samples were measured and the results are shown in Fig. 7. The UV vis spectrum of pure $\mathrm{CdTiO}_{3}$ sample (curve (i) in Fig. 7(a)) shows a strong absorption 

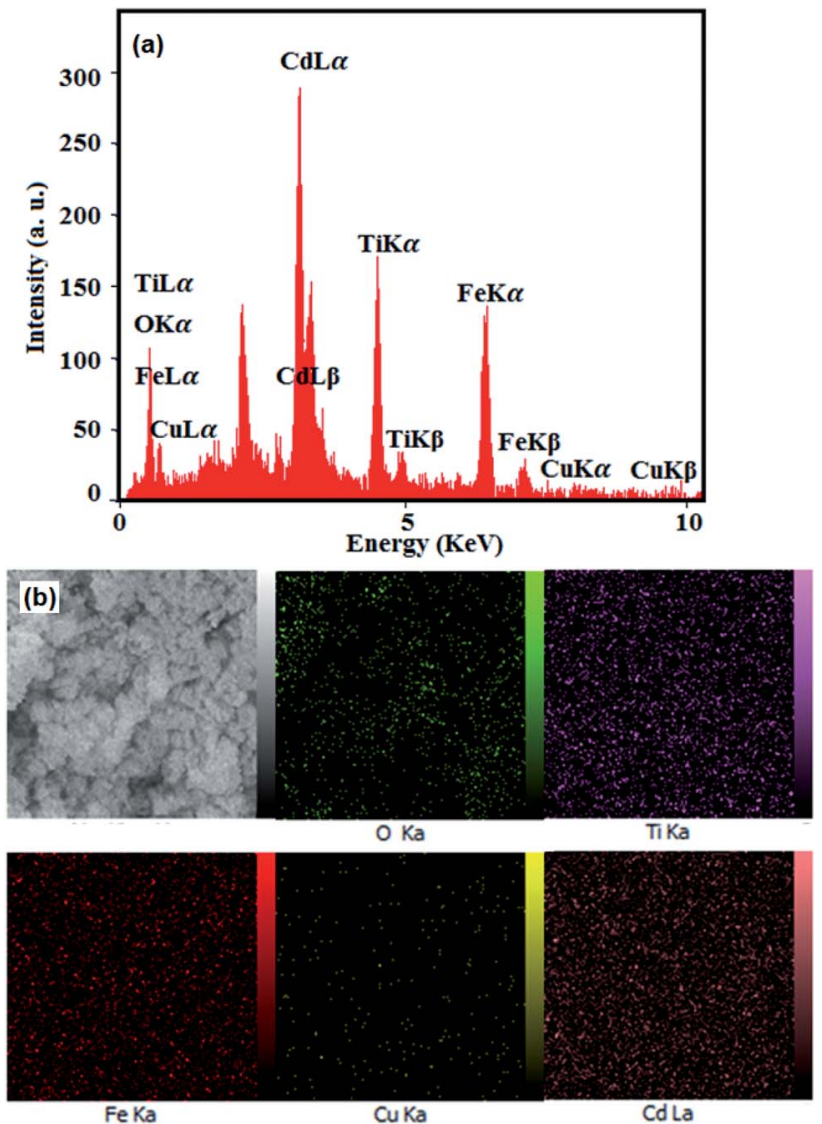

Fig. 4 (a) EDX spectrum and (b) elemental mappings of the $\mathrm{CdTiO}_{3} /$ $\mathrm{CuFe}_{2} \mathrm{O}_{4}$ nanocomposite.

band from the UV to the visible light region with a clear absorption edge at $460 \mathrm{~nm}$. The UV vis spectrum of $\mathrm{CuFe}_{2} \mathrm{O}_{4}$ sample (curve (ii) in Fig. 7(a)) exhibits a broad absorption band in the visible range. However, after coupling $\mathrm{CdTiO}_{3}$ with $\mathrm{CuFe}_{2} \mathrm{O}_{4}$, the obtained composite exhibited a wide absorption band that covered the whole visible region (curve (iii) in Fig. $7(\mathrm{a})$ ). The $\mathrm{CdTiO}_{3} / \mathrm{CuFe}_{2} \mathrm{O}_{4}$ had a significant red-shift toward the visible light region. Obviously, the visible light absorption of $\mathrm{CdTiO}_{3} / \mathrm{CuFe}_{2} \mathrm{O}_{4}$ heterojunction is better than that of $\mathrm{CdTiO}_{3}$, which possibly results good visible-light utilization. The band gap energy $\left(E_{\mathrm{g}}\right)$ of samples can be deducted
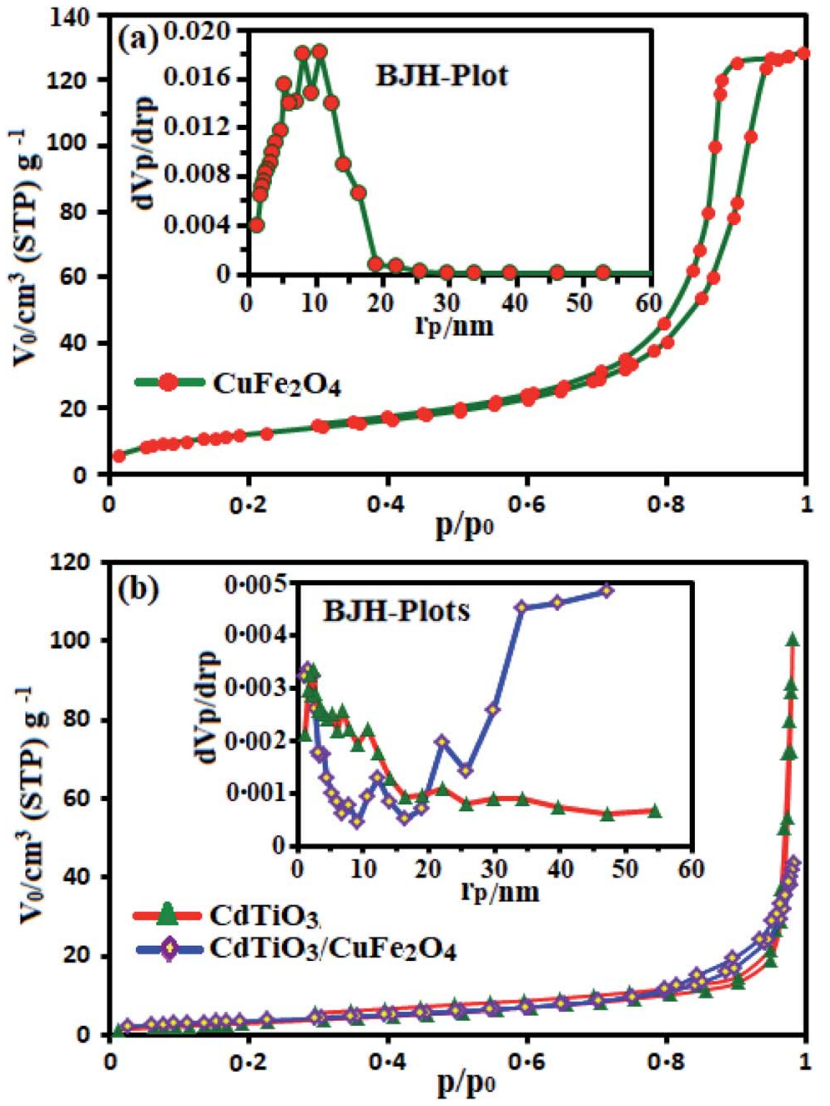

Fig. 6 Nitrogen adsorption-desorption isotherms of (a) pure $\mathrm{CuFe}_{2} \mathrm{O}_{4}$ and (b) pristine $\mathrm{CdTiO}_{3}$ and $\mathrm{CdTiO}_{3} / \mathrm{CuFe}_{2} \mathrm{O}_{4}$ nanocomposite samples. The insets show pore size distribution curves.

from the formula: ${ }^{55}(\alpha h \nu)^{2}=B\left(h \nu-E_{\mathrm{g}}\right)$, where $\alpha, \nu$, and $B$ are absorption coefficient, light frequency and proportionality constant, respectively. The $(\alpha h v)^{2}$ versus $h v$ curves for $\mathrm{CdTiO}_{3}$, $\mathrm{CuFe}_{2} \mathrm{O}_{4}$ and $\mathrm{CdTiO}_{3} / \mathrm{CuFe}_{2} \mathrm{O}_{4}$ nanocomposites are shown in Fig. $7(\mathrm{~b})$. The value of $h v$ extrapolated to $\alpha=0$ gives the absorption band gap energy. From Fig. 7(b), curves (i)-(iii), the band gap energies were estimated to be $3.55,1.55$ and $2.20 \mathrm{eV}$ for $\mathrm{CdTiO}_{3}, \mathrm{CuFe}_{2} \mathrm{O}_{4}$ and $\mathrm{CdTiO}_{3} / \mathrm{CuFe}_{2} \mathrm{O}_{4}$ nanocomposite samples, respectively, indicating that the introduction of $\mathrm{CuFe}_{2} \mathrm{O}_{4}$ decreased the $E_{\mathrm{g}}$ of $\mathrm{CdTiO}_{3}$. Furthermore, the decrease
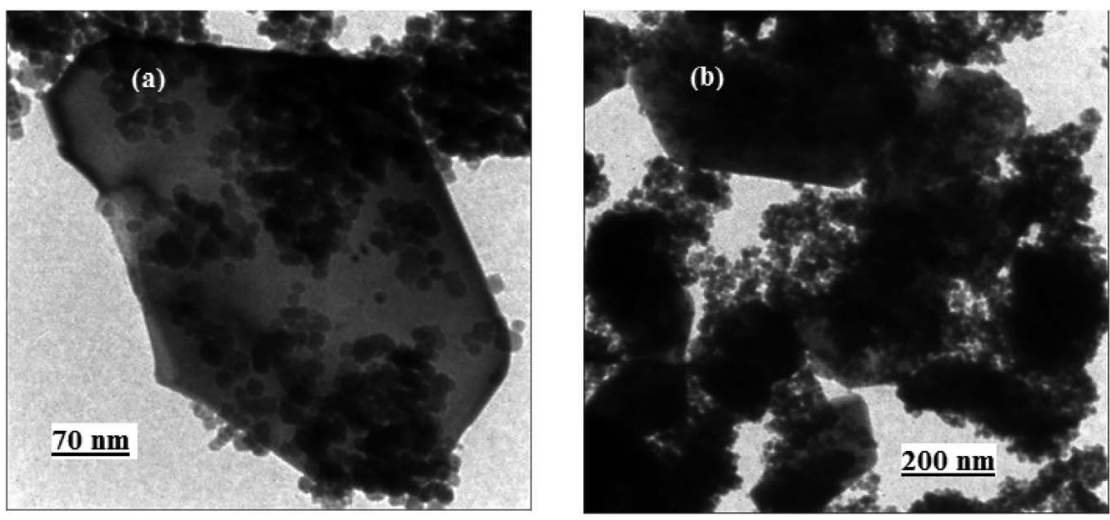

Fig. 5 TEM images of the $\mathrm{CdTiO}_{3} / \mathrm{CuFe}_{2} \mathrm{O}_{4}$ nanocomposite. 
Table 1 The textural properties of as-prepared samples

\begin{tabular}{llll}
\hline Sample & BET surface area $\left(S_{\mathrm{BET}}, \mathrm{m}^{2} \mathrm{~g}^{-1}\right)$ & Total pore volume $\left(V_{\mathrm{p}}, \mathrm{cm}^{3} \mathrm{~g}^{-1}\right)$ & Average pore diameter $\left(r_{\mathrm{p}}, \mathrm{nm}\right)$ \\
\hline $\mathrm{CuFe}_{2} \mathrm{O}_{4}$ & 43.512 & 0.199 & 10.65 \\
$\mathrm{CdTiO}_{3}$ & 14.023 & 0.156 & 47.22 \\
$\mathrm{CdTiO}_{3} / \mathrm{CuFe}_{2} \mathrm{O}_{4}$ & 13.514 & 0.068 & 19.99
\end{tabular}

of $E_{\mathrm{g}}$ upon composite formation confirms electronic coupling between $\mathrm{CdTiO}_{3}$ and $\mathrm{CuFe}_{2} \mathrm{O}_{4}$. The visible light photocatalytic activity of $\mathrm{CdTiO}_{3} / \mathrm{CuFe}_{2} \mathrm{O}_{4}$ could be attributed to the existence of this broad band with the $E_{\mathrm{g}}$ of $2.20 \mathrm{eV}$. After the decoration of $\mathrm{CuFe}_{2} \mathrm{O}_{4}$ on the surface of $\mathrm{CdTiO}_{3}, \mathrm{CdTiO}_{3} / \mathrm{CuFe}_{2} \mathrm{O}_{4}$ heterojunction displays a broad photoabsorption from ultraviolet to visible light with an edge around $750 \mathrm{~nm}$. This fact reveals that $\mathrm{CdTiO}_{3} / \mathrm{CuFe}_{2} \mathrm{O}_{4}$ heterojunction has a broad photoabsorption region, resulting in great potential as an excellent visible light driven photocatalyst.

\subsection{Magnetic properties analysis}

Fig. 8 shows magnetization hysteresis curves of the $\mathrm{CuFe}_{2} \mathrm{O}_{4}$ and $\mathrm{CdTiO}_{3} / \mathrm{CuFe}_{2} \mathrm{O}_{4}$ nanocomposite at room-temperature. The
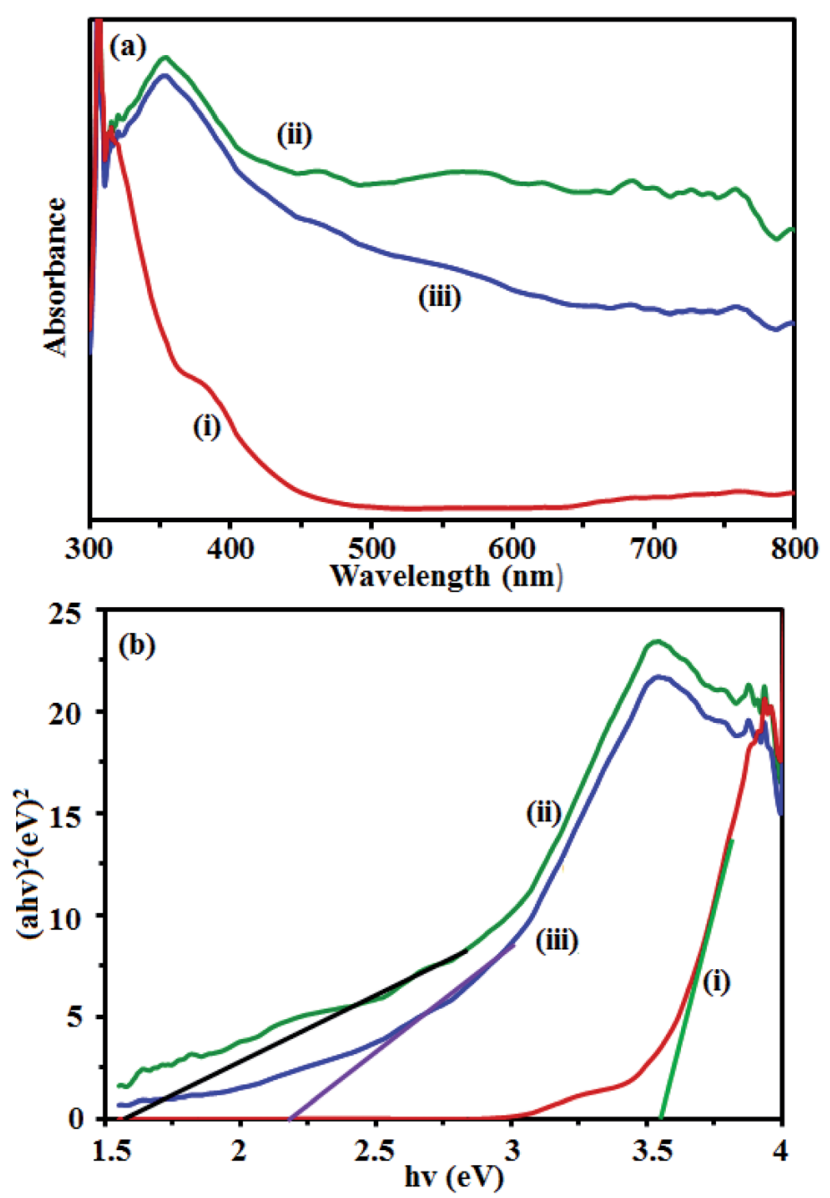

Fig. 7 (a) UV-vis DRS and (b) band gap energies of: (i) $\mathrm{CdTiO}_{3}$, (ii) $\mathrm{CuFe}_{2} \mathrm{O}_{4}$ and (iii) $\mathrm{CdTiO}_{3} / \mathrm{CuFe}_{2} \mathrm{O}_{4}$ nanocomposite. samples exhibit zero coercivity $\left(H_{\mathrm{c}}=0\right)$ and near-zero remanence magnetization $\left(M_{\mathrm{r}} \sim 0\right)$ at room temperature, reflecting their superparamagnetic properties. However, because of the presence of diamagnetic $\mathrm{CdTiO}_{3}$, the saturation magnetization of $\mathrm{CdTiO}_{3} / \mathrm{CuFe}_{2} \mathrm{O}_{4}$ nanocomposite is reduced to $19.17 \mathrm{emu} \mathrm{g}^{-1}$ as compared with that of pure $\mathrm{CuFe}_{2} \mathrm{O}_{4}\left(55.03 \mathrm{emu} \mathrm{\textrm {g } ^ { - 1 }}\right)$. The composite still exhibits superparamagnetic characteristics. As shown in the inset of Fig. 8, the $\mathrm{CdTiO}_{3} / \mathrm{CuFe}_{2} \mathrm{O}_{4}$ nanocomposite could be easily separated from the wastewater with a common magnet and quickly collected on the side of the glass vial in a short time, which indicates that $\mathrm{CdTiO}_{3} / \mathrm{CuFe}_{2} \mathrm{O}_{4}$ nanocomposite can be easily recycled from wastewater by external magnetic field and it can be readily re-dispersed back into the aqueous phase due to its zero coercivity. ${ }^{56}$ The facile separation and recovery of $\mathrm{CdTiO}_{3} / \mathrm{CuFe}_{2} \mathrm{O}_{4}$ composite is very favorable for its practical applications.

\subsection{Photocatalytic performance}

The photocatalytic activity of $\mathrm{CdTiO}_{3} / \mathrm{CuFe}_{2} \mathrm{O}_{4}$ nanocomposite was evaluated by $\mathrm{H}_{2} \mathrm{O}_{2}$-assisted degradation of organic dyes in aqueous solutions under visible light irradiation. As shown in Fig. 9(a), the intense absorption peak of MB dye at 664 gradually decreased in during the different reaction times and disappeared after $90 \mathrm{~min}$. Also, color change of the MB solution from blue to almost colorless with increasing irradiation time indicated its complete degradation. The control experiments

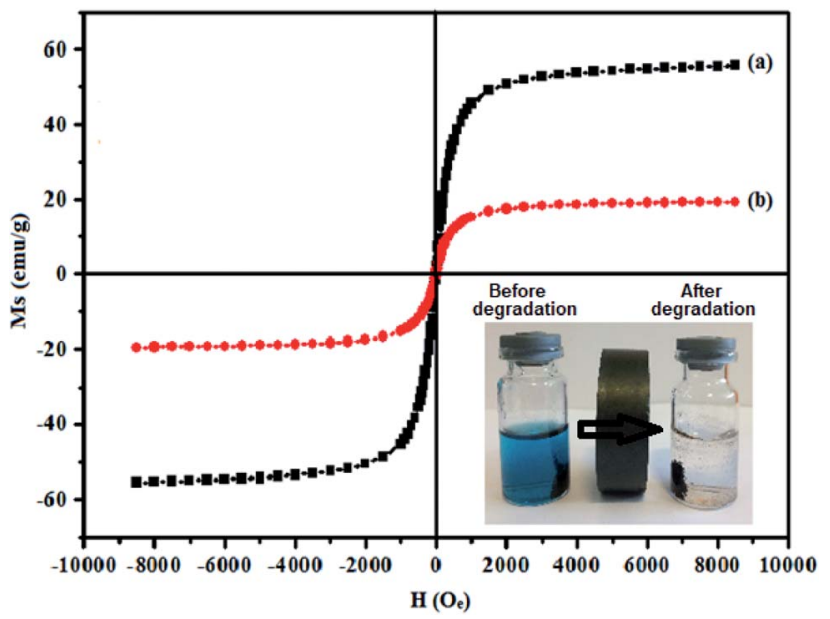

Fig. 8 Room-temperature magnetic hysteresis loops of (a) pure $\mathrm{CuFe}_{2} \mathrm{O}_{4}$ and (b) $\mathrm{CdTiO}_{3} / \mathrm{CuFe}_{2} \mathrm{O}_{4}$ nanocomposite. The photo inset shows magnetic separation of the photocatalyst from aqueous dye solution before and after dye degradation using a magnet. 
were carried out under different conditions. The results of MB dye degradation rate are shown in Fig. 9(b). Curve (I) in Fig. 9(b) shows that $\mathrm{MB}$ decomposition is negligible without the catalyst and $\mathrm{H}_{2} \mathrm{O}_{2}$ under visible light irradiation. $\mathrm{CdTiO}_{3} / \mathrm{CuFe}_{2} \mathrm{O}_{4}$ nanocomposite (without $\mathrm{H}_{2} \mathrm{O}_{2}$ ) under visible light irradiation degraded $23 \%$ of $\mathrm{MB}$ (curve (II)). The photodegradation efficiency of $\mathrm{MB}$ in the presence of $\mathrm{H}_{2} \mathrm{O}_{2}$ alone (without catalyst) was $21 \%$ (curve (III)). $\mathrm{CdTiO}_{3} / \mathrm{H}_{2} \mathrm{O}_{2}$ system removed only $18 \%$ of $\mathrm{MB}$ dye (curve (IV)) in $90 \mathrm{~min}$ whereas $\mathrm{CuFe}_{2} \mathrm{O}_{4} / \mathrm{H}_{2} \mathrm{O}_{2}$ system degraded MB dye about $61 \%$ at the same time (curve (V)). The degradation percentage of $\mathrm{MB}$ by $\mathrm{CdTiO}_{3} / \mathrm{CuFe}_{2} \mathrm{O}_{4}$ nanocomposite in the presence of $\mathrm{H}_{2} \mathrm{O}_{2}$ without visible light illumination (in the dark) was $72 \%$ (curve (VI)). Curve (VII) in Fig. 9(b) shows photocatalytic capability $\mathrm{CdTiO}_{3} / \mathrm{CuFe}_{2} \mathrm{O}_{4} / \mathrm{H}_{2} \mathrm{O}_{2}$ system under visible light irradiation that indicates the highest photocatalytic activity, $100 \%$ of $\mathrm{MB}$ was degraded in $90 \mathrm{~min}$. Thus, it can be concluded that complete degradation of MB dye occurs when simultaneously $\mathrm{CdTiO}_{3} / \mathrm{CuFe}_{2} \mathrm{O}_{4}$ nanocomposite and $\mathrm{H}_{2} \mathrm{O}_{2}$ are present in the reaction solution under visible light irradiation. In order to study the photocatalytic degradation rate of $\mathrm{MB}$ under different conditions, a pseudo-first-order kinetic model was used (eqn (2)), and the results were displayed in Fig. 9(c).

$$
\ln \left(C_{0} / C\right)=k_{\mathrm{app}} t
$$

where, $C_{0}$ and $C$ are the $\mathrm{MB}$ concentrations before and after visible light irradiation, respectively, $k_{\text {app }}$ is the pseudo-first- order rate constant and $t$ is irradiation time. The slope of the line of $\ln \left(C / C_{0}\right)$ vs. $t$ is reaction rate constant $\left(k_{\text {app }}\right)$. From Fig. 9(c), the $k_{\text {app }}$ values for visible light irradiation alone, $\mathrm{H}_{2} \mathrm{O}_{2} /$ vis, $\mathrm{CuFe}_{2} \mathrm{O}_{4} / \mathrm{H}_{2} \mathrm{O}_{2} /$ vis, $\mathrm{CdTiO}_{3} / \mathrm{H}_{2} \mathrm{O}_{2} /$ vis, $\mathrm{CdTiO}_{3} / \mathrm{CuFe}_{2} \mathrm{O}_{4} /$ $\mathrm{H}_{2} \mathrm{O}_{2}, \mathrm{CdTiO}_{3} / \mathrm{CuFe}_{2} \mathrm{O}_{4} /$ vis and $\mathrm{CdTiO}_{3} / \mathrm{CuFe}_{2} \mathrm{O}_{4} / \mathrm{H}_{2} \mathrm{O}_{2} /$ vis were calculated to be $0,0.0043,0.0107,0.005,0.0165,0.0024$ and $0.049 \mathrm{~min}^{-1}$, respectively. The kinetic rate constant of $\mathrm{CdTiO}_{3} /$ $\mathrm{CuFe}_{2} \mathrm{O}_{4}$ nanocomposite is much higher than those of other catalyst samples. Based on the above results, one can conclude that $\mathrm{CdTiO}_{3} / \mathrm{CuFe}_{2} \mathrm{O}_{4}$ nanocomposite is much more active than pristine $\mathrm{CdTiO}_{3}$ and pure $\mathrm{CuFe}_{2} \mathrm{O}_{4}$.

3.8.1. Effect of $\mathrm{H}_{2} \mathrm{O}_{2}$ concentration. To investigate the influence of $\mathrm{H}_{2} \mathrm{O}_{2}$ concentration on $\mathrm{MB}$ degradation, a series of experiments were done with different amounts of $\mathrm{H}_{2} \mathrm{O}_{2}$, while the initial concentration of dye and other parameters were constant and the results are presented in Fig. 10(a). It is clear that the degradation rate of $\mathrm{MB}$ dye increased with increasing $\mathrm{H}_{2} \mathrm{O}_{2}$ amount. At higher concentration of $\mathrm{H}_{2} \mathrm{O}_{2}$, more ${ }^{\circ} \mathrm{OH}$ radicals were achieved. Therefore, the photodegradation activity was improved. ${ }^{57}$

3.8.2. Effect of photocatalyst dosage. Fig. 10(b) shows the effect of photocatalyst amount on the MB degradation under visible light illumination. It can be clearly seen that with the increase of the catalyst amount from 10 to $50 \mathrm{mg}$, the degradation rate of $\mathrm{MB}$ dye in aqueous solution increased. This may be due to the increase in active sites resulting from higher amount of catalyst which generate more ${ }^{\circ} \mathrm{OH}$ radicals and facilitate the further and faster degradation of dye molecules. ${ }^{58}$
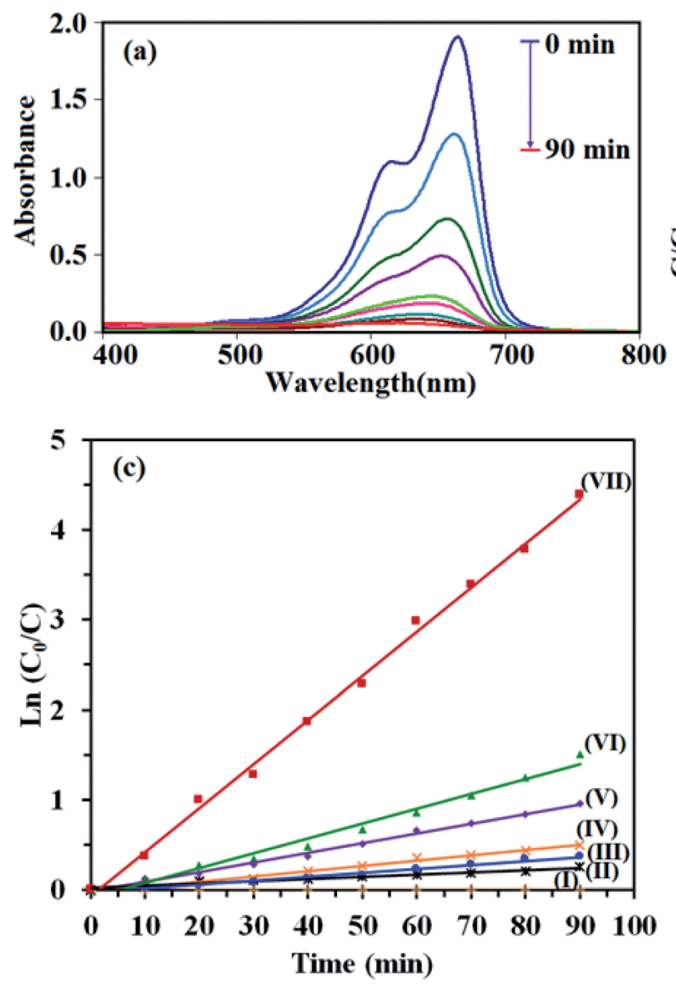

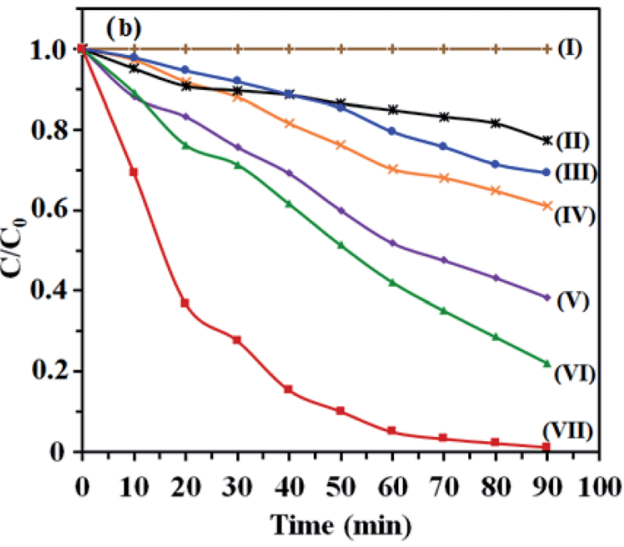

$$
\begin{aligned}
& \text { (I) }- \text { Visible light only } \\
& \text { (II) } * \mathrm{CdTiO}_{3} / \mathrm{CuFe}_{2} \mathrm{O}_{4}+\mathrm{Vis} \\
& \text { (III) } \rightarrow \mathrm{H}_{2} \mathrm{O}_{2}+\mathrm{Vis} \\
& \text { (IV) } * \mathrm{CdTiO}_{3}+\mathrm{H}_{2} \mathrm{O}_{2}+\mathrm{Vis} \\
& \text { (V) } \rightarrow \mathrm{CuFe}_{2} \mathrm{O}_{4}+\mathrm{H}_{2} \mathrm{O}_{2}+\mathrm{Vis} \\
& \text { (VI) } \leftarrow \mathrm{CdTiO}_{3} / \mathrm{CuFe}_{2} \mathrm{O}_{4}+\mathrm{H}_{2} \mathrm{O}_{2} \\
& \text { (VII) }-\mathrm{CdTiO}_{3} / \mathrm{CuFe}_{2} \mathrm{O}_{4}+\mathrm{H}_{2} \mathrm{O}_{2}+\mathrm{Vis}
\end{aligned}
$$

Fig. 9 (a) Photocatalytic degradation of MB under different conditions. (b) Concentration changes of MB at $664 \mathrm{~nm}$ as a function of irradiation time. (c) Plot of $\ln \left(C_{0} / C\right)$ against the irradiation time. Conditions: $M B\left(25 \mathrm{mg} \mathrm{L}^{-1}, 30 \mathrm{~mL}\right), \mathrm{H}_{2} \mathrm{O}_{2}(0.15 \mathrm{M})$, catalyst $\left(1 \mathrm{~g} \mathrm{~L}{ }^{-1}\right)$ and reaction time of $90 \mathrm{~min}$. 

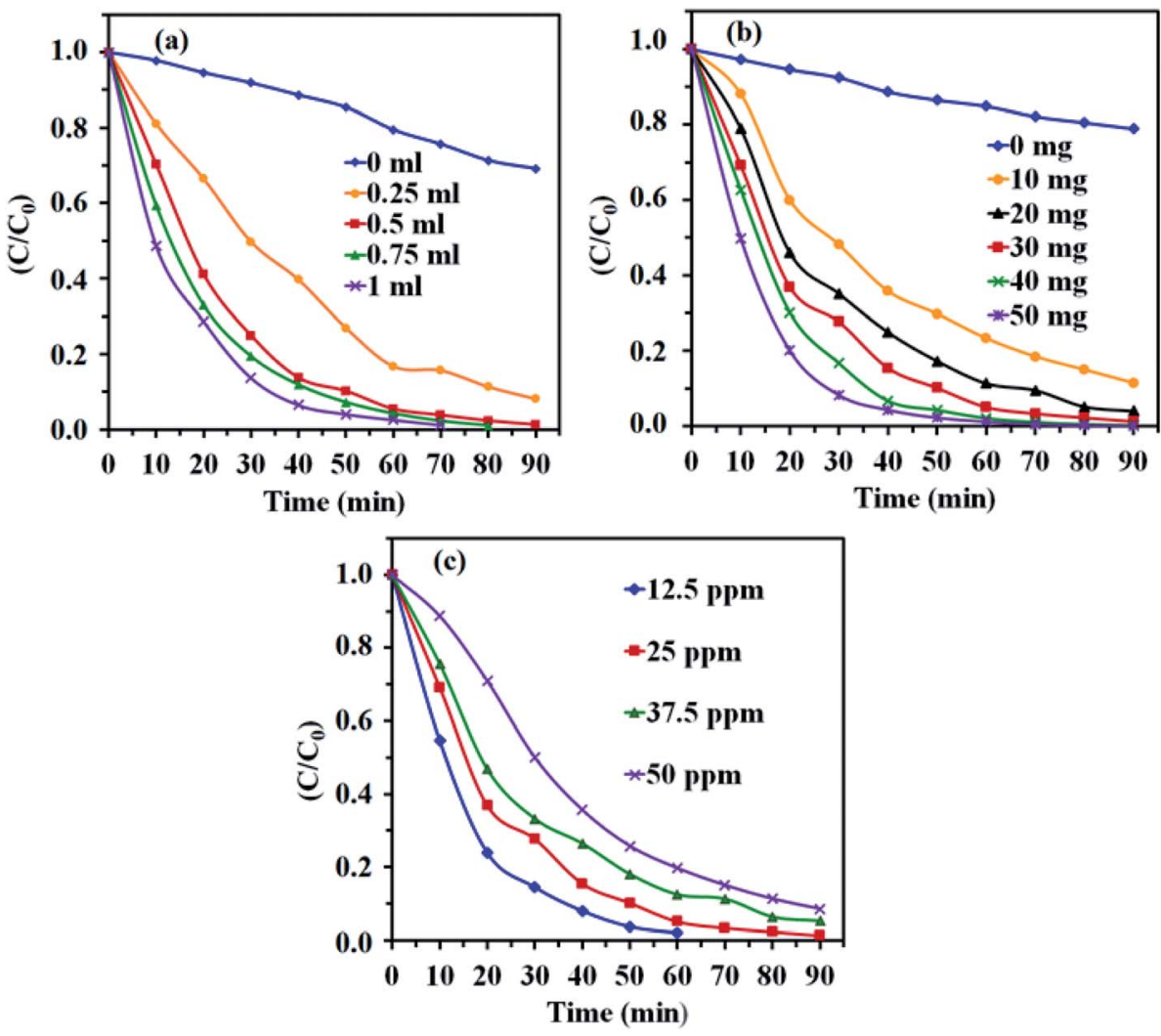

Fig. 10 Effects of (a) $\mathrm{H}_{2} \mathrm{O}_{2}$ amount, (b) $\mathrm{CdTiO}_{3} / \mathrm{CuFe}_{2} \mathrm{O}_{4}$ dosage and (c) initial dye concentration on the photocatalytic degradation. Conditions: $\mathrm{MB}\left(25 \mathrm{mg} \mathrm{L}^{-1}, 30 \mathrm{~mL}\right), \mathrm{H}_{2} \mathrm{O}_{2}(0.15 \mathrm{M})$, catalyst $(30 \mathrm{mg})$ and time $=90 \mathrm{~min}$.

3.8.3. Effect of initial concentration of MB. Fig. 10(c) shows the effect of the initial MB concentration on its photocatalytic degradation percentage. For this purpose, different initial concentration of MB from 12.5 to $50 \mathrm{mg} \mathrm{L}^{-1}$ was studied under visible light irradiation. As shown in Fig. 10(c), a more time needed to achieve the suitable degradation at higher concentration of $\mathrm{MB}$ dye. At a constant catalyst dosage, amount of $\mathrm{H}_{2} \mathrm{O}_{2}$, and reaction time, the number of generated ${ }^{\circ} \mathrm{OH}$ radicals for the degradation the dye molecules remains constant with increasing dye initial concentration, resulting degradation efficiency decreases. ${ }^{\mathbf{5 9 , 6 0}}$

To study the scope of this method, the photocatalytic degradation of MO and RhB dyes was also evaluated. Accordingly, similar experiments were performed and the results are shown in Fig. 11. As shown in Fig. 11(a) and (b), the RhB and MO dyes were degraded completely in 90 and $100 \mathrm{~min}$, respectively. The slower degradation of MO molecules can be related to its high redox potential. As compared in Fig. 11(c), this novel photocatalytic system exhibits excellent capacity for the degradation of $\mathrm{MB}, \mathrm{RhB}$ and $\mathrm{MO}$ under visible light irradiation.

To check the effectiveness of our photocatalyst, the degradation efficiency of the present work was compared with some of the earlier reported photocatalysts ${ }^{61-80}$ and the results are presented in Table 2. It is clear that the earlier studies have utilized high power xenon and mercury lights for the degradation of low concentration of dyes (5-10 $\left.\mathrm{mg} \mathrm{L}^{-1}\right)$ with more quantity of photocatalyst (50-300 mg) and longer times (100-300 min). From Table 2, it can be seen that our catalyst showed higher degradation efficiency for high concentration dye with less amount of photocatalyst in lesser time under mild conditions in visible light when contrasted with the other most reported works. These results affirmed that our photocatalyst is more superior and/or is better than that of those observed in the previous reports.

\subsection{Possible photocatalytic mechanism}

The above results reveal that $\mathrm{CdTiO}_{3} / \mathrm{CuFe}_{2} \mathrm{O}_{4}$ nanocomposite exhibits a higher photocatalytic activity than those of pristine $\mathrm{CdTiO}_{3}$ and pure $\mathrm{CuFe}_{2} \mathrm{O}_{4}$. The enhanced photocatalytic activity of $\mathrm{CdTiO}_{3} / \mathrm{CuFe}_{2} \mathrm{O}_{4}$ can be attributed to the synergetic effects of strong visible-light absorption and $\mathrm{p}-\mathrm{n}$ junction structure causing effective separation of photo generated holes and electrons. $\mathrm{CuFe}_{2} \mathrm{O}_{4}$ is a p-type semiconductor with a narrow band gap while $\mathrm{CdTiO}_{3}$ is an n-type semiconductor with a large band gap. ${ }^{81}$ The positions of the conduction band (CB) and valence band (VB) of n-type $\mathrm{CdTiO}_{3}$ and p-type $\mathrm{CuFe}_{2} \mathrm{O}_{4}$ can be computed using the atom's Mulliken electronegativity definition (eqn (3) and (4)): ${ }^{82}$

$$
\begin{gathered}
E_{\mathrm{VB}}=\chi-E^{\mathrm{e}}+1 / 2 E_{\mathrm{g}} \\
E_{\mathrm{CB}}=E_{\mathrm{VB}}-E_{\mathrm{g}}
\end{gathered}
$$

where $E_{\mathrm{VB}}$ is the VB potential, $E_{\mathrm{CB}}$ is the CB potential, $E^{\mathrm{e}}$ is the energy of free electrons on the hydrogen scale (ca. $4.5 \mathrm{eV}), E_{\mathrm{g}}$ is 

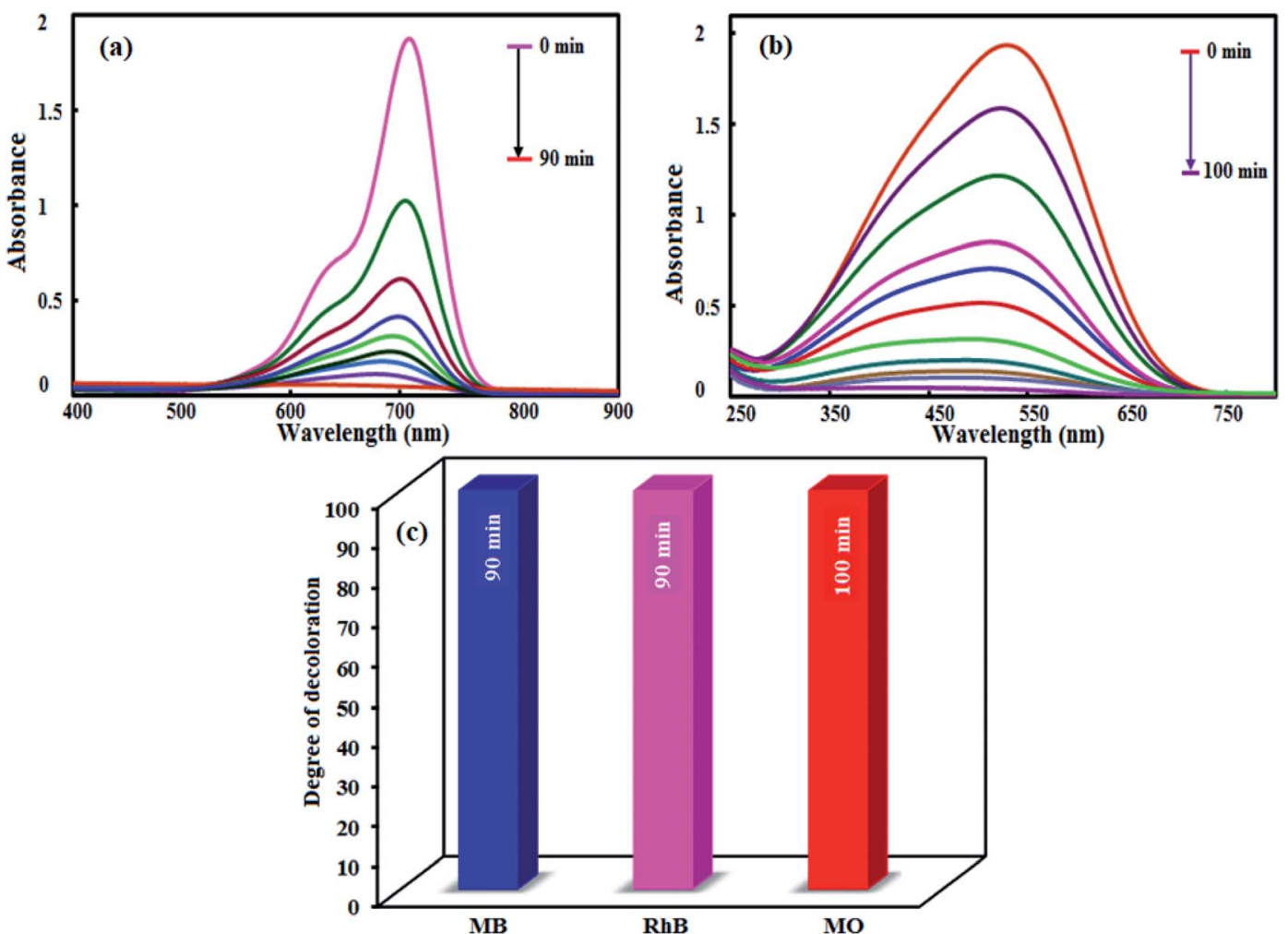

Fig. 11 Photocatalytic degradation of (a) RhB and (b) MO. (c) Comparison of the photocatalytic degradation of $M B$, RhB and MO dyes. Conditions: [dye] $=25 \mathrm{mg} \mathrm{L}^{-1}$; [catalyst] $=0.1 \mathrm{~g} \mathrm{~L}^{-1} ;\left[\mathrm{H}_{2} \mathrm{O}_{2}\right]=0.15 \mathrm{~mol} \mathrm{~L}-1$ and reaction times of $90-100 \mathrm{~min}$.

the band gap energy and $\chi$ is the absolute electronegativity of the semiconductor. On the basis of the above equations, the $E_{\mathrm{VB}}$ and $E_{\mathrm{CB}}$ of n-CdTiO ${ }_{3}$ were calculated to be $1.08 \mathrm{eV}$ and $-2.47 \mathrm{eV}$, whereas the potentials for $\mathrm{CuFe}_{2} \mathrm{O}_{4}$ were estimated to be $0.27 \mathrm{eV}$ and $-1.28 \mathrm{eV}$, respectively.
According to the above results, the energy band schematic diagram for $\mathrm{CuFe}_{2} \mathrm{O}_{4}$ and $\mathrm{CdTiO}_{3}$ were illustrated in Fig. 12. The band gap of $\mathrm{CdTiO}_{3}$ is $3.55 \mathrm{eV}$ and thus it cannot be excited under visible light irradiation. However, $\mathrm{CuFe}_{2} \mathrm{O}_{4}$ with the band gap of $1.55 \mathrm{eV}$ can be easily excited to generate holes and

Table 2 Comparison of visible-light-driven photocatalytic performance of $\mathrm{CdTiO} / \mathrm{CuFe}_{2} \mathrm{O}_{4}$ nanocomposite with other reported nanomaterials

\begin{tabular}{|c|c|c|c|c|c|c|}
\hline Photocatalyst & Irradiation source & Dyes & $\begin{array}{l}{[\text { Dye] }} \\
\left(\mathrm{mg} \mathrm{L}^{-1}\right)\end{array}$ & $\begin{array}{l}\text { Volume (mL)/ } \\
\text { catalyst (mg) }\end{array}$ & $\begin{array}{l}\text { Degradation(\%) } \\
\text { /time (min) }\end{array}$ & Ref. \\
\hline $\mathrm{CdTiO}_{3} / \mathrm{CuFe}_{2} \mathrm{O}_{4}$ & $400 \mathrm{~W} \mathrm{Hg} \operatorname{lamp}(\lambda \geq 420 \mathrm{~nm})$ & MB \& RhB & 25 & $30 / 30$ & $100 / 90$ & This work \\
\hline $\mathrm{CdTiO}_{3}$ & UV $\operatorname{lamp}(\lambda \geq 300 \mathrm{~nm})$ & R6G & 10 & $100 / 100$ & $100 / 300$ & 61 \\
\hline $\mathrm{CuFe}_{2} \mathrm{O}_{4} / \mathrm{TiO}_{2}$ & $250 \mathrm{~W}$ High pressure $\mathrm{Hg}$ lamp & MB & 12 & $100 / 100$ & $47 / 150$ & 62 \\
\hline $\mathrm{TiO}_{2} / \mathrm{PbTiO}_{3}$ & $300 \mathrm{~W}$ High pressure $\mathrm{Hg} \operatorname{lamp}(\lambda \geq 420 \mathrm{~nm})$ & MB & $\sim 3.2$ & $65 / 300$ & $80 / 300$ & 63 \\
\hline $\mathrm{TiO}_{2} / \mathrm{Fe}_{3} \mathrm{O}_{4}$ & $250 \mathrm{~W}$ High pressure $\mathrm{Hg} \operatorname{lamp}(\lambda \geq 300 \mathrm{~nm})$ & RhB & 10 & $60 / 200$ & $96.3 / 80$ & 64 \\
\hline $\mathrm{ZnO} / \mathrm{CdS}$ & Sun light & RhB & 5 & $80 / 20$ & $100 / 90$ & 65 \\
\hline $\mathrm{rGO} / \mathrm{MoS}_{2}$ & SOL2/500S lamp $(\lambda \geq 295 \mathrm{~nm})$ & MB & 12.5 & $8.5 / 6.5$ & $95 / 300$ & 66 \\
\hline $\mathrm{P} 25 / \mathrm{CoFe}_{2} \mathrm{O}_{4}$ /graphene & $500 \mathrm{~W}$ Xenon lamp & $\mathrm{MB}$ & 40 & $30 / 30$ & $100 / 240$ & 67 \\
\hline Graphene $/ \mathrm{TiO}_{2} / \mathrm{Fe}_{3} \mathrm{O}_{4}$ & $300 \mathrm{~W} \mathrm{Hg}$ lamp & RhB & 5 & $50 / 10$ & $100 / 25$ & 68 \\
\hline $\mathrm{g}-\mathrm{C}_{3} \mathrm{~N}_{4} / \mathrm{Fe}_{3} \mathrm{O}_{4} / \mathrm{BiOI}$ & 50 W LED lamp (visible-light source) & $\mathrm{MB}$ & $\sim 4$ & $250 / 100$ & $98 / 180$ & 69 \\
\hline $\mathrm{LaFeO}_{3} / \mathrm{GrO}$ & $300 \mathrm{~W}$ Xe arc lamp $(\lambda>400 \mathrm{~nm}$ & MB & 0.5 & $100 / 10$ & $98 / 70$ & 70 \\
\hline $\mathrm{LaFeO}_{3} / \mathrm{g}-\mathrm{C}_{3} \mathrm{~N}_{4}$ & $500 \mathrm{~W}$ Xe arc lamp $(\lambda \geq 420 \mathrm{~nm})$ & RhB & 15 & $100 / 20$ & $85 / 160$ & 71 \\
\hline $\mathrm{Bi}_{2} \mathrm{~S}_{3} / \mathrm{Bi}_{2} \mathrm{O}_{2} \mathrm{CO}_{3}$ & $300 \mathrm{~W}$ Xe lamp $(\lambda>400 \mathrm{~nm})$ & $\mathrm{RhB}$ & 10 & $50 / 50$ & $100 / 30$ & 72 \\
\hline $\mathrm{CdS} / \mathrm{Bi}_{2} \mathrm{O}_{2} \mathrm{CO}_{3}$ & $300 \mathrm{~W}$ Xe $\operatorname{lamp}(\lambda>400 \mathrm{~nm})$ & MB & 10 & $50 / 40$ & $67 / 90$ & 73 \\
\hline $\mathrm{CdS} / \mathrm{ZnFe}_{2} \mathrm{O}_{4}$ & $500 \mathrm{~W}$ Xe lamp $(\lambda>400 \mathrm{~nm})$ & RhB & 10 & $100 / 50$ & $98 / 60$ & 74 \\
\hline $\mathrm{CuFe}_{2} \mathrm{O}_{4} / \mathrm{g}-\mathrm{C}_{3} \mathrm{~N}_{4}$ & $300 \mathrm{~W}$ Tungsten light lamp $(\lambda \geq 400 \mathrm{~nm})$ & RhB & 10 & $100 / 50$ & $90 / 150$ & 75 \\
\hline $\mathrm{Ag}_{3} \mathrm{PO}_{4} / \mathrm{GO} / \mathrm{NiFe}_{2} \mathrm{O}_{4}$ & $300 \mathrm{~W}$ Xe arc lamps $(\lambda \geq 400 \mathrm{~nm})$ & RhB & 10 & $100 / 20$ & $98 / 30$ & 76 \\
\hline $\mathrm{SrTiO}_{3} / \mathrm{NiFe}_{2} \mathrm{O}_{4}$ & $500 \mathrm{~W}$ Xe $\operatorname{lamp}(\lambda \geq 400 \mathrm{~nm})$ & RhB & 20 & $100 / 100$ & $100 / 120$ & 77 \\
\hline $\mathrm{Ag}_{3} \mathrm{PO}_{4} / \mathrm{MgFe}_{2} \mathrm{O}_{4}$ & $300 \mathrm{~W}$ Xe arc lamp $(\lambda \geq 400 \mathrm{~nm})$ & RhB & 10 & $100 / 20$ & $100 / 30$ & 78 \\
\hline $\mathrm{SrTiO}_{3} / \mathrm{TiO}_{2}$ & 50 W High-pressure $\mathrm{Hg} \operatorname{lamp}(\mathrm{UV}, \lambda \geq 313 \mathrm{~nm})$ & RhB & 10 & $100 / 10$ & $100 / 60$ & 79 \\
\hline $\mathrm{MoS}_{2} / \mathrm{Fe}_{3} \mathrm{O}_{4}$ & $500 \mathrm{~W}$ High-pressure xenon lamp $(\lambda \geq 420 \mathrm{~nm})$ & MB & 30 & $-/ 25$ & $98 / 120 \mathrm{~min}$ & 80 \\
\hline
\end{tabular}




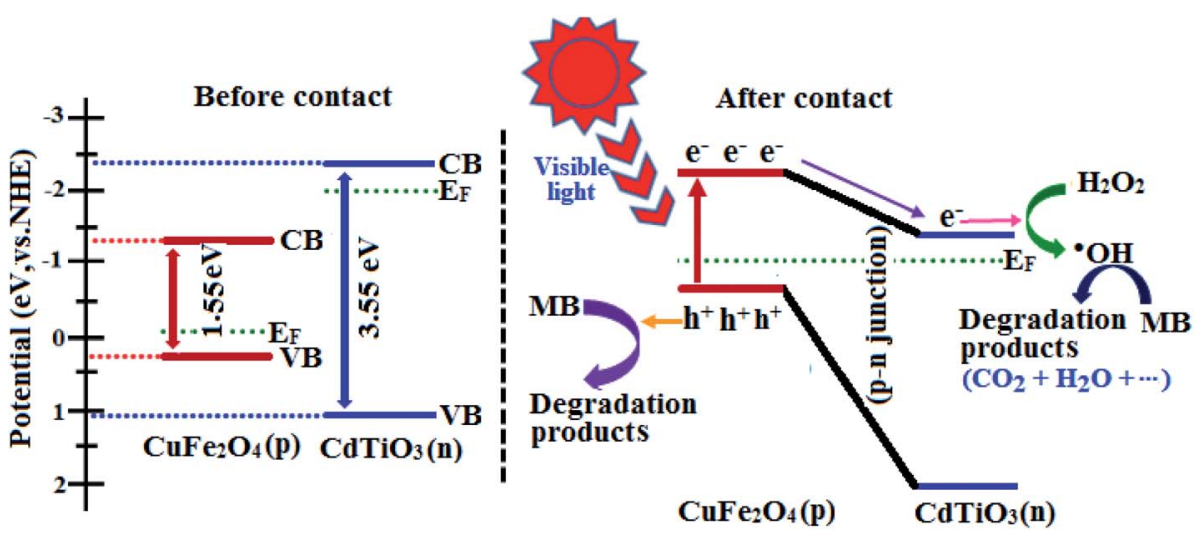

Fig. 12 Schematic illustration of excitation and separation of photoinduced electron-hole pairs for $\mathrm{CdTiO}_{3} / \mathrm{CuFe}_{2} \mathrm{O}_{4}$ heterojunction under visible-light irradiation.

electrons under visible light irradiation in its $\mathrm{VB}$ and $\mathrm{CB}$, respectively. Before contact, the conduction band and Fermi level $\left(E_{\mathrm{f}}\right)$ position of $\mathrm{CuFe}_{2} \mathrm{O}_{4}$ is lower than those of $\mathrm{CdTiO}_{3}$. In the case of contact between p-type $\mathrm{CuFe}_{2} \mathrm{O}_{4}$ and n-type $\mathrm{CdTiO}_{3}$, the electrons will diffusion from $\mathrm{CdTiO}_{3}$ to $\mathrm{CuFe}_{2} \mathrm{O}_{4}$ due to the more negative $\mathrm{CB}$ of $\mathrm{CdTiO}_{3}$, which results in accumulation of negative charges in $\mathrm{CuFe}_{2} \mathrm{O}_{4}$ close to the junction. ${ }^{71,83}$ Meanwhile, a positive section in $\mathrm{CdTiO}_{3}$ near the junction will generate after the holes transfer from $\mathrm{CuFe}_{2} \mathrm{O}_{4}$ to $\mathrm{CdTiO}_{3}$. The Fermi energy level of $\mathrm{CuFe}_{2} \mathrm{O}_{4}$ is moved up, and simultaneously the Fermi level of $\mathrm{CdTiO}_{3}$ is moved down to form an equilibrium state, where the inner electric field is formed and the $\mathrm{CB}$ of $\mathrm{CuFe}_{2} \mathrm{O}_{4}$ is higher than that of $\mathrm{CdTiO}_{3}$. Under visible-light illumination, $\mathrm{CuFe}_{2} \mathrm{O}_{4}$ could be easily excited and induced the generation of photoelectrons and holes. According to the schematic diagram in Fig. 12, the excited electrons on the $\mathrm{CB}$ of the $\mathrm{CuFe}_{2} \mathrm{O}_{4}$ transfer to that of $\mathrm{CdTiO}_{3}$, and simultaneous the holes remain in the $\mathrm{VB}$ of $\mathrm{CuFe}_{2} \mathrm{O}_{4}{ }^{84}$ The internal electric field can promote the migration of photogenerated carriers. Accordingly, the p-n junction formed in the $\mathrm{CdTiO}_{3} / \mathrm{CuFe}_{2} \mathrm{O}_{4}$ interface will be beneficial for separation of the photogenerated electron-hole pairs, and the recombination probability of electron-hole pairs can be consequently reduced.$^{85}$ The separated electrons and holes are then free to initiate reactions with the dye molecules adsorbed on the photocatalyst surfaces. The photogenerated electrons will be used to active $\mathrm{H}_{2} \mathrm{O}_{2}$ to produce hydroxyl radicals ( $\left.{ }^{\circ} \mathrm{OH}\right)$. Some of holes maybe directly involved in the oxidation of $\mathrm{MB}$ to produce unstable $\mathrm{MB}^{+}$as a target of $\mathrm{OH}^{-}$attack. On the other hand, the produced hydroxyl radicals ( $\left.{ }^{\circ} \mathrm{OH}\right)$ resulting from reaction of the electrons in CB with $\mathrm{H}_{2} \mathrm{O}_{2}$ were active enough to degrade $\mathrm{MB}$ to the innocent products $\mathrm{CO}_{2}$ and $\mathrm{H}_{2} \mathrm{O}$, etc. (eqn (5)-(9)). ${ }^{86}$

$$
\begin{gathered}
\mathrm{CdTiO}_{3} / \mathrm{CuFe}_{2} \mathrm{O}_{4}+h v \rightarrow \mathrm{e}_{\mathrm{CB}}{ }^{-}+\mathrm{h}_{\mathrm{VB}}{ }^{+} \\
\mathrm{H}_{2} \mathrm{O}_{2}+\mathrm{e}_{\mathrm{CB}}{ }^{-} \rightarrow{ }^{\circ} \mathrm{OH}+\mathrm{OH}^{-} \\
\mathrm{h}_{\mathrm{VB}}{ }^{+}+\mathrm{OH}^{-} \rightarrow \cdot \mathrm{OH} \\
\mathrm{MB}+\mathrm{h}_{\mathrm{VB}}{ }^{+} \rightarrow \mathrm{MB}^{+} \text {(unstable) } \\
\mathrm{MB}^{+}+{ }^{\cdot} \mathrm{OH} \rightarrow \mathrm{CO}_{2}+\mathrm{H}_{2} \mathrm{O}+\ldots
\end{gathered}
$$

The separation of photoexcited carriers was further validated by their photoluminescence (PL) property. Fig. 13(a) exhibits the room-temperature PL spectra of pristine $\mathrm{CdTiO}_{3}$ and $\mathrm{CdTiO}_{3} /$ $\mathrm{CuFe}_{2} \mathrm{O}_{4}$. The pristine $\mathrm{CdTiO}_{3}$ nanoparticles show the PL spectrum with high intensity, indicating high radiative recombination. Moreover, $\mathrm{CdTiO}_{3} / \mathrm{CuFe}_{2} \mathrm{O}_{4}$ heterojunction has a similar peak shape and peak position, but much lower PL intensity, suggesting that the sample possessed the high separation efficiency of photogenerated electrons and holes. The
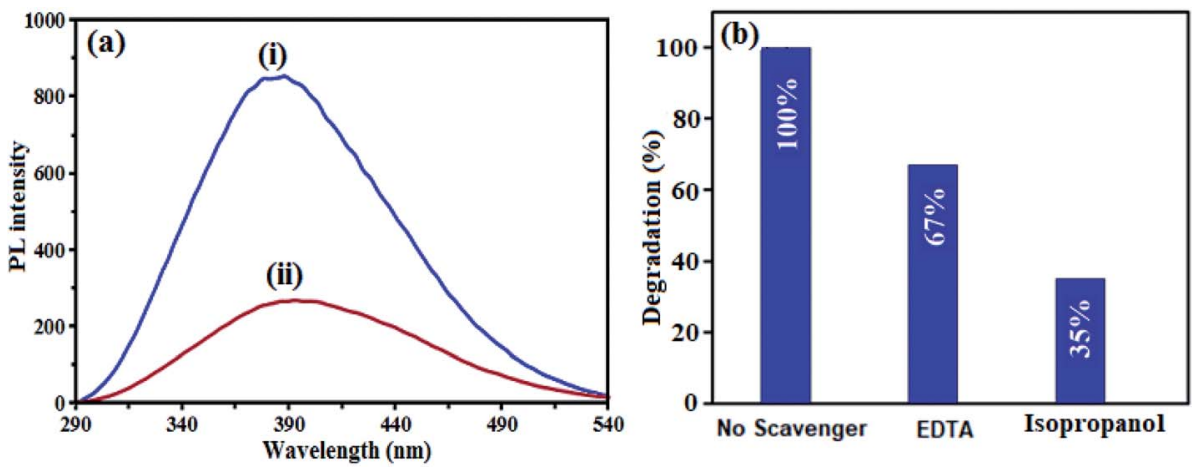

Fig. 13 (a) $\mathrm{PL}$ spectra excited at $325 \mathrm{~nm}$ of (i) pure $\mathrm{CdTiO}_{3}$ and (ii) $\mathrm{CdTiO}_{3} / \mathrm{CuFe}_{2} \mathrm{O}_{4}$ samples and (b) the photocatalytic degradation of $\mathrm{MB}$ over the $\mathrm{CdTiO} / \mathrm{CuFe}_{2} \mathrm{O}_{4}$ in the presence of different scavengers under visible-light irradiation. 

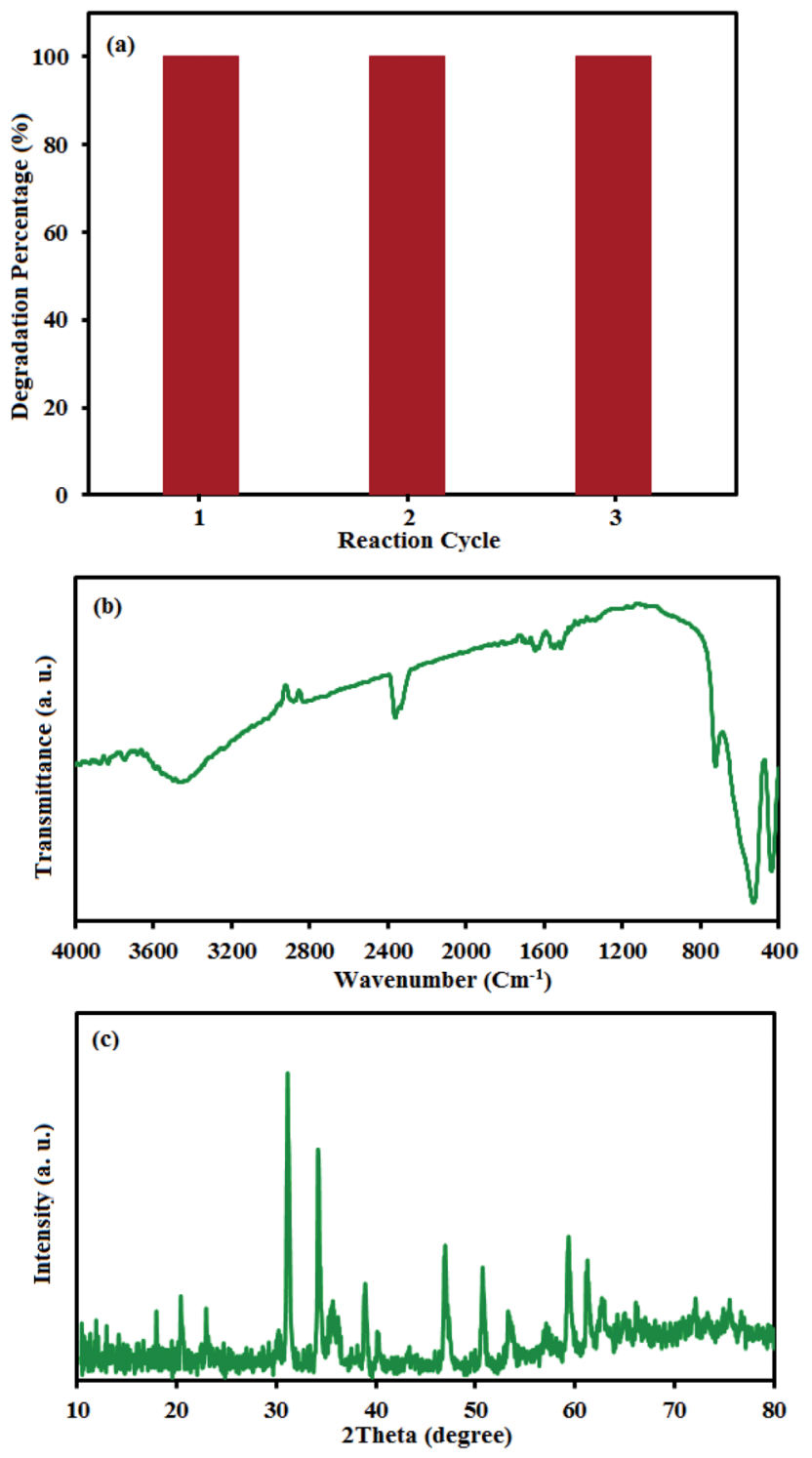

Fig. 14 (a) Cycling runs of $\mathrm{CdTiO}_{3} / \mathrm{CuFe}_{2} \mathrm{O}_{4}$ in the photodegradation of MB. Each run of photocatalytic reactions lasted for $90 \mathrm{~min}$. (b) XRD and (c) FT-IR of the recovered nanocomposite after the 3rd run.

results indicated that the $\mathrm{CdTiO}_{3} / \mathrm{CuFe}_{2} \mathrm{O}_{4}$ heterojunction is favorable at suppressing radiative recombination. This led to better utilization of electron and hole pairs induced by light irradiation.

To further evaluate what kind of species plays a main role in the photo degradation process of dyes, in this reaction system, isopropanol and disodium ethylenediamine tetraacetate (EDTA) were used as be the scavengers of ${ }^{\circ} \mathrm{OH}$ radicals and holes $\left(\mathrm{h}_{\mathrm{VB}}{ }^{+}\right)$, respectively. As shown in Fig. 13(b), EDTA decreased the photodegradation rate slightly, demonstrating the minor role of holes $\left(\mathrm{h}_{\mathrm{VB}}{ }^{+}\right)$. In contrast, the photocatalytic degradation efficiency of $\mathrm{MB}$ decreases significantly in the presence of isopropanol, demonstrating that ${ }^{\circ} \mathrm{OH}$ radicals play a main role in the photocatalytic degradation of MB. According to these results, it can be concluded that ${ }^{\circ} \mathrm{OH}$ radicals are the major active species in the photocatalytic reaction, and holes were less involved.

\subsection{Recyclability and stability tests}

The reusability of photocatalysts is a noteworthy issue in practical applications, especially for the separation property and their stability. The $\mathrm{CdTiO}_{3} / \mathrm{CuFe}_{2} \mathrm{O}_{4}$ nanocomposite has magnetism due to the presence of $\mathrm{CuFe}_{2} \mathrm{O}_{4}$ nanoparticles. To confirm the magnetic properties of the $\mathrm{CdTiO}_{3} / \mathrm{CuFe}_{2} \mathrm{O}_{4}$, a separation experiment was conducted as follows. The inset of Fig. 4 showed that the $\mathrm{CdTiO}_{3} / \mathrm{CuFe}_{2} \mathrm{O}_{4}$ has magnetic properties that can solve the separation problem of photocatalysts via magnetic separation. The $\mathrm{CdTiO}_{3} / \mathrm{CuFe}_{2} \mathrm{O}_{4}$ was reused three times to test the stability of $\mathrm{CdTiO}_{3} / \mathrm{CuFe}_{2} \mathrm{O}_{4}$ nanocomposite on the photodegradation of MB. After each photocatalytic degradation experiment, the nanocomposite was separated from the dye solution by a permanent magnet, washed with distilled water, dried at $60{ }^{\circ} \mathrm{C}$ and used in a new cycle. As shown in Fig. 14(a), the recycled catalyst activity showed no significant change after three recycles. The amounts of $\mathrm{Cu}, \mathrm{Fe}$ and $\mathrm{Cd}$ metals in the filtrate were also determined to be about less than $0.1 \%$ by ICP-AES analysis. In addition, XRD and FT-IR spectra of the fresh and recycled catalyst did not exhibit obvious differences even after three cycling runs (Fig. 14(b) and (c)). These findings confirm the composite has a good stability during the photocatalytic degradation of dyes.

\section{Conclusion}

In summary, a novel magnetically recyclable $\mathrm{CdTiO}_{3} / \mathrm{CuFe}_{2} \mathrm{O}_{4}$ nanocomposite was successfully constructed by attachment of spherical $\mathrm{CuFe}_{2} \mathrm{O}_{4}$ nanoparticles onto the surface of $\mathrm{CdTiO}_{3}$ nanoplates via a sol-gel hydrothermal process for the first time. The photocatalytic activity of $\mathrm{CdTiO}_{3} / \mathrm{CuFe}_{2} \mathrm{O}_{4}$ nanocomposite is significantly enhanced for removal of organic dyes under visible light irradiation. The enhanced photodegradation performance can be attributed to the promoted separation and inhibited recombination of electron-holes pairs in the heterostructures of $\mathrm{CdTiO}_{3} / \mathrm{CuFe}_{2} \mathrm{O}_{4}$ nanocomposites. Moreover, the excellent room temperature superparamagnetism and stability of $\mathrm{CdTiO}_{3} / \mathrm{CuFe}_{2} \mathrm{O}_{4}$ nanocomposites ensure the convenient magnetic separation. Since the unique $\mathrm{CdTiO}_{3} / \mathrm{CuFe}_{2} \mathrm{O}_{4}$ material with high activity and recyclable magnetic separation, it has potential applications in organic pollutant removal and environmental remediation.

\section{Conflicts of interest}

There are no conflicts of interest to declare.

\section{Acknowledgements}

The authors gratefully acknowledge the Lorestan University and Iran Nanotechnology Initiative Council (INIC) for their financial support.

\section{References}

1 K. Ji, J. Deng, H. Zang, J. Han, H. Arandiyan and H. Dai, Appl. Catal., B, 2015, 165, 285-295. 
2 S. Kansal, M. Singh and D. Sud, J. Hazard. Mater., 2007, 141, 581-590.

3 M. Saranya, R. Ramachandran, E. J. J. Samuel, S. K. Jeong and A. N. Grace, Powder Technol., 2015, 279, 209-220.

4 R. Jain and M. Shrivastava, J. Hazard. Mater., 2008, 152, 216220.

5 H. Wang, X.-W. Zheng, J.-Q. Su, Y. Tian, X.-J. Xiong and T.-L. Zheng, J. Hazard. Mater., 2009, 171, 654-659.

6 K. Kumari and T. E. Abraham, Bioresour. Technol., 2007, 98, 1704-1710.

7 M. M. Pendergast and E. M. Hoek, Energy Environ. Sci., 2011, 4, 1946-1971.

8 N. Harsha, K. S. Krishna, N. K. Renuka and S. Shukla, RSC Adv., 2015, 5, 30354-30362.

9 K. Li, F. Chai, Y. Zhao and X. Guo, RSC Adv., 2015, 5, 9439794404.

10 K. Soutsas, V. Karayannis, I. Poulios, A. Riga, K. Ntampegliotis, X. Spiliotis and G. Papapolymerou, Desalination, 2010, 250, 345-350.

11 D. Xu, B. Cheng, S. Cao and J. Yu, Appl. Catal., B, 2015, 164, 380-388.

12 F. Z. Yehia, N. G. Kandile, A. M. Badawi and A. H. Mady, Clean: Soil, Air, Water, 2012, 40, 692-697.

13 J. Ding, W. Yan, S. Sun, J. Bao and C. Gao, ACS Appl. Mater. Interfaces, 2014, 6, 12877-12884.

14 S. Farhadi and F. Siadatnasab, Desalin. Water Treat., 2017, 66, 299-308.

15 Y. Yao, L. Wang, L. Sun, S. Zhu, Z. Huang, Y. Mao, W. Lu and W. Chen, Chem. Eng. Sci., 2013, 101, 424-431.

16 Y. Yao, Y. Cai, F. Lu, F. Wei, X. Wang and S. Wang, J. Hazard. Mater., 2014, 270, 61-70.

17 Y. Yang, J. J. Pignatello, J. Ma and W. A. Mitch, Environ. Sci. Technol., 2014, 48, 2344-2351.

18 H. Tong, S. Ouyang, Y. Bi, N. Umezawa, M. Oshikiri and J. Ye, Adv. Mater., 2012, 24, 229-251.

19 S. Sepahvand and S. Farhadi, RSC Adv., 2018, 8, 1012410140.

20 F. L. Zhang, Z. Q. Cheng, L. Y. Cui, T. T. Duan, C. F. Zhang and L. J. Kang, RSC Adv., 2016, 6, 1844-1850.

21 H. Y. Zhu, R. Jiang, Y. Q. Fu, R. R. Li, J. Yao and S. T. Jiang, Appl. Surf. Sci., 2016, 369, 1-10.

22 T. H. Yu, W. Y. Cheng, K. J. Chao and S. Y. Lu, Nanoscale, 2013, 5, 7356-7360.

23 B. Chai, J. Li, Q. Xu and K. Dai, Mater. Lett., 2014, 120, 177181.

24 S. Z. Zhao, Z. Q. Cheng, L. J. Kang, Y. Y. Zhang and X. D. Zhao, Mater. Lett., 2016, 182, 305-308.

25 K. Nakata and A. Fujishima, J. Photochem. Photobiol., C, 2012, 13, 169-189.

26 H. Li, T. X. Zhang, C. Pan, C. C. Pu, Y. Hu, X. Y. Hu, E. Z. Liu and J. Fan, Appl. Surf. Sci., 2017, 391, 303-310.

27 Y. Wang, J. Sunarsoc, B. Zhao, C. H. Ge and G. H. Chen, Ceram. Int., 2017, 43, 15769-15776.

28 M. Ge, Y. Y. Chen, M. L. Liu and M. Li, J. Environ. Chem. Eng., 2015, 3, 2809-2815.

29 K. Lakhera, A. Watts, H. Y. Hafeez and B. Neppolian, Catal. Today, 2018, 300, 58-70.
30 Y. Xia, Z. He, J. Su, B. Tang, K. Hu, Y. Lu, S. Sun and X. Li, RSC Adv., 2018, 8, 4284-4294.

31 Z.-Q. Song, S.-B. Wang, W. Yang, M. Li, H. Wang and H. Yan, Mater. Sci. Eng., B, 2004, 113, 121-124.

32 R. Marandi, A. Sharif, M. Olya and R. Moradi, J. Basic Appl. Sci. Res., 2013, 3, 443-456.

33 C. Karunakaran and A. Vijayabalan, Mater. Sci. Semicond. Process., 2013, 16, 1992-1996.

34 B. Pant, H. R. Pant, N. A. Barakat, M. Park, T.-H. Han, B. H. Lim and H.-Y. Kim, Ceram. Int., 2014, 40, 1553-1559.

35 H. Wang, X. X. Zhang, A. P. Huang, H. Y. Xu, M. K. Zhu, B. Wang, H. Yan and M. Yoshimura, J. Cryst. Growth, 2002, 246, 150-154.

36 A. R. Phani and S. Santucci, J. Phys.: Condens. Matter, 2006, 18, 6965-6978.

37 S. A. Bakar, S. T. Hussain and M. Mazhar, New J. Chem., 2012, 36, 1844-1851.

38 A. R. Phani, M. Passacantando and S. Santucci, J. Mater. Sci., 2000, 35, 5295-5299.

39 Z. Imran, S. S. Batool, H. Jamil, M. Usman, M. Israr-Qadir, S. H. Shah, S. Jamil-Rana, M. A. Rafiq, M. M. Hasan and M. Willander, Ceram. Int., 2013, 39, 457-462.

40 M. de Anda Reyes, G. T. Delgado, R. C. Pérez, J. M. Marín and O. Z. Angel, J. Photochem. Photobiol., A, 2012, 228, 22-27.

41 H. Wang, L. Zhang, Z. Chen, J. Hu, S. Li, Z. Wang, J. Liu and X. Wang, Chem. Soc. Rev., 2014, 43, 5234-5244.

42 E. Casbeer, V. K. Sharma and X.-Z. Li, Sep. Purif. Technol., 2012, 87, 1-14.

43 S. Saadi, A. Bouguelia and M. Trari, Renewable Energy, 2006, 31, 2245-2256.

44 H. Yang, J. Yan, Z. Lu, X. Cheng and Y. Tang, J. Alloys Compd., 2009, 476, 715-719.

45 A. Kezzim, N. Nasrallah, A. Abdi and M. Trari, Energy Convers. Manage., 2011, 52, 2800-2806.

46 R. Cheng, X. Fan, M. Wang, M. Li, J. Tian and L. Zhang, RSC Adv., 2016, 6, 18990-18995.

47 Y. Ding, L. Zhu, N. Wang and H. Tang, Appl. Catal., B, 2013, 129, 153-162.

48 S. Rus, P. Vlazan, S. Novaconi, P. Sfirloaga and I. Grozescu, J. Optoelectron. Adv. Mater., 2012, 14, 293-297.

49 M. Salavati-Niasari, F. Soofivand, A. Sobhani-Nasab, M. Shakouri-Arani, M. Hamadanian and S. Bagheri, J. Mater. Sci.: Mater. Electron., 2017, 28, 14965-14973.

50 M. Zhu, D. Meng, C. Wang and G. Diao, ACS Appl. Mater. Interfaces, 2013, 5, 6030-6037.

51 M. S. Hassan, T. Amna and M. S. Khil, Ceram. Int., 2014, 40, 423-427.

52 H. P. Klug and L. E. Alexander, X-ray diffraction procedures: for polycrystalline and amorphous materials, Wiley-VCH, 2nd edition, 1974.

53 L. Li, X. D. Huang, T. Y. Hu, J. X. Wang, W. Z. Zhang and J. Q. Zhang, New J. Chem., 2014, 38, 5293-5302.

54 L. Y. Yang, G. P. Feng, T. X. Wang, J. M. Zhang and T. J. Lou, Mater. Lett., 2011, 65, 2601-2603.

55 T. I. Draskovic, M. Z. Yu and Y. Y. Wu, Inorg. Chem., 2015, 54, 5519-5526. 
56 L. Zou, H. Wang, G. Yuan and X. Wang, ACS Appl. Nano Mater., 2018, 1, 831-838.

57 R. Liang, S. Luo, F. Jing, L. Shen, N. Qin and L. Wu, Appl. Catal., B, 2015, 176, 240-248.

58 N. Ertugay and F. N. Acar, Appl. Surf. Sci., 2014, 318, 121-126.

59 Z. Frontistis and D. Mantzavinos, Ultrason. Sonochem., 2012, 19, 77-84.

60 R. Darvishi Cheshmeh Soltani, A. Khataee and M. Mashayekhi, Desalin. Water Treat., 2016, 57, 1349413504.

61 Y. Yao, Y. Cai, F. Lu, J. Qin, F. Wei, C. Xu and S. Wang, Ind. Eng. Chem. Res., 2014, 53, 17294-17302.

62 H. A. Mourão, A. R. Malagutti and C. Ribeiro, Appl. Catal., A, 2010, 382, 284-292.

63 L. Li, Y. Zhang, A. M. Schultz, X. Liu, P. A. Salvador and G. S. Rohrer, Catal. Sci. Technol., 2012, 2, 1945-1952.

64 Y. Yao, F. Lu, Y. Zhu, F. Wei, X. Liu, C. Lian and S. Wang, J. Hazard. Mater., 2015, 297, 224-233.

65 S. Kandula and P. Jeevanandam, J. Nanopart. Res., 2014, 16, 2452.

66 S. Cravanzola, F. Cesano, G. Magnacca, A. Zecchina and D. Scarano, $R S C$ Adv., 2016, 6, 59001-59008.

67 J. Sun, Y. Fu, P. Xiong, X. Sun, B. Xuc and X. Wang, RSC Adv., 2013, 3, 22490-22497.

68 Y. Shi, K. Zhou, B. Wang, S. Jiang, X. Qian, Z. Gui, R. K. K. Yuen and Y. Hu, J. Mater. Chem. A, 2014, 2, 535-544.

69 M. Mousavi and A. Habibi-Yangjeh, J. Colloid Interface Sci., 2016, 465, 83-92.

70 X. Ren, H. T. Yang, S. Gen, J. Zhou, T. Z. Yang, X. Q. Zhang, Z. H. Cheng and S. H. Sun, Nanoscale, 2016, 8, 752-756.

71 Q. Liang, J. Jin, C. Liu, S. Xu and Z. Li, J. Alloys Compd., 2017, 709, 542-548.
72 N. Liang, J. Zai, M. Xu, Q. Zhu, X. Wei and X. Qian, J. Mater. Chem. A, 2014, 2, 4208-4216.

73 Y. Ao, L. Xu, P. Wang, C. Wang, J. Hou and J. Qian, Dalton Trans., 2015, 44, 11321-11330.

74 P. Xiong, J. Zhu and X. Wang, Ind. Eng. Chem. Res., 2013, 52, 17126-17133.

75 J. Y. Shen, Z. S. Cui, Z. W. Wu, J. X. Wang, Q. Ning and X. M. Lu, Mater. Res. Innovations, 2015, 19, 187-191.

76 T. Zhou, G. Zhang, H. Yang, H. Zhang, R. Suo, Y. Xie and G. Liu, $R S C A d v$., 2018, 8, 28179-28188.

77 Y. Xia, Z. He, Y. Lu, B. Tang, S. Sun, J. Su and X. Li, RSC Adv., 2018, 8, 5441-5450.

78 T. Zhou, G. Zhang, P. Ma, X. Qiu, H. Zhang, H. Yang and G. Liu, J. Alloys Compd., 2018, 735, 1277-1290.

79 T. Cao, Y. Li, C. Wang, C. Shao and Y. Liu, Langmuir, 2011, 27, 2946-2952.

80 Q. Wang, S. Dong, D. Zhang, C. Yu, J. Lu, D. Wang and J. Sun, J. Mater. Sci., 2018, 53, 1135-1147.

81 S. Abu-Bakar, S. T. Hussain and M. Mazhar, New J. Chem., 2012, 36, 1844-1851.

82 J. Theerthagiri, R. Senthil, A. Priya, J. Madhavan, R. Michael and M. Ashokkumar, RSC Adv., 2014, 4, 38222-38229.

83 G. P. Dai, J. G. Yu and G. Liu, J. Phys. Chem. C, 2011, 115, 7339-7346.

84 D. L. Jiang, L. L. Chen, J. J. Zhu, M. Chen, W. D. Shi and J. M. Xie, Dalton Trans., 2013, 42, 15726-15734.

85 W. J. Yin, L. J. Bai, Y. Z. Zhu, S. X. Zhong, L. H. Zhao, Z. Q. Li and S. Bai, ACS Appl. Mater. Interfaces, 2016, 8, 23133-23142.

86 F.-J. Zhang, M.-L. Chen, K. Zhang and W.-C. Oh, Bull. Korean Chem. Soc., 2010, 31, 133-139. 